\title{
FOSSIL PROBOSCIDEA AND EDENTATA OF THE SAN PEDRO VALLEY, ARIZONA
}

\author{
By James Williams Gidley
}

\section{INTRODUCTION}

A preliminary report on the fossil vertebrates of the San Pedro Valley, Ariz., collected by Kirk Bryan and $m e$ in the winter of 1920 and 1921 was published in 1922.1 This report includes a brief statement regarding the geology of the locality and a preliminary list of fossil vertebrates obtained by the expedition of 1921, with descriptions of the rodents and rabbits. Two additional papers on this interesting fauna have also appeared, one on the turtles by C. W. Gilmore ${ }^{2}$ and one on the birds by Alexander Wetmore. ${ }^{3}$ The present contribution deals with the proboscideans and edentates and gives a somewhat fuller discussion of the geology of the fossil-bearing beds.

\section{GEOLOGY AND FAUNAL ASPECT OF THE SAN PEDRO VALLEY DEPOSITS}

As stated in the preliminary report, most of the material collected came from two localities, which seem to be slightly different in age. One of these is on the west side of the valley near the town of Benson; the other is on the east side of the valley in the vicinity of the Curtis Flats, about 12 miles from the Benson locality Stratigraphically and structurally the beds of these two localities seem to be equivalent in age. The faunas of the two localities, however, seem to belong to slightly different time periods. In fact, the collection obtained from one locality differs so widely from that of the other-there being no species in commonthat the deposits evidently represent two distinct time periods. These faunas, however, contain several genera in common, and the species are so nearly related as to indicate that the time interval between the two periods represented was probably not great. Further study of the material seems to sustain my first impression that the fossil-bearing beds near Benson are slightly older than the Blanco formation of Texas, and that the beds near Curtis Flats are somewhat younger. It must be admitted, however, that this opinion is not based on any very tangible or direct evidence, and more comparisons should be made, especially with the Blanco faunas. In its favor is the fact that the beds of the Benson locality contain remains of a mastodon with enamel-banded tusks, Neohipparion, Protohippus (or Pliohippus), Merycodus, and other forms of distinctly Miocene or Pliocene affinities, whereas the Stegomastodon and Glyptotherium of the Curtis Flats locality seem closely related to but slightly more progressive

1 U. S. Geol. Survey Prof. Paper 131, pp. 119-131, 1922.

2 U. S. Nat. Mus. Proc., vol. 61, pp. 1-8, pls. 1-5, 1922.

3 U. S. Nat. Mus. Proc., vol. 64, art. 5, pp. 1-18, figs. 1-9, 1924. than species of these genera found in the Blanco formation. The presence of true Equus, which was found in the Curtis Flats locality and in one place south of the Benson locality, will doubtless be considered by some as evidence of Pleistocene age. However, the fact must be taken into account that the occurrence of this genus in the Pleistocene is confined to the earlier stages, and also that even there it is represented by several well-defined species of diversified character, ranging in size from a Shetland pony to a draft horse. It must therefore be admitted that the gerus Equus, as at present defined, must have had a very considerable period of development prior to its first general appearance in the regions of our best-known collecting fields of Pleistocene age, both in America and in Europe. If this is true it would not be surprising, and in fact it might be expected, that occasional advance guards of the later general invasion of this genus reached America long before the beginning of Pleistocene time. In my opinion this is just what happened in the San Pedro Valley and other localities of the extreme West.

Even more puzzling than the question of exact correlation of the San Pedro Valley faunas with those of other areas is the apparent disagreement, to which I have already referred, of the geologic and faunistic evidence relative to the respective time phases of the two adjacent localities here under discussion. A detailed study of the deposits themselves, however, seems to offer a solution.

As surveyed and reported by Bryan, ${ }^{4}$ the deformed valley fill, which includes the fossil-bearing beds, occurs in a strip lying on both sides of San Pedro River from the Mexican boundary north to Gila River. This material consists of cemented gravel and conglomerate, which generally bos:der the mountains, and of finer material, which in general occupies the middle and lower parts of the valley. The formation as a whole is the result of deposition in an arid intermontane valley. It has been deformed and faulted by renewed uplift of the bordering mountains, but in general the finer-grained beds in the center of the valley were little affected by these movements and for the most part are undisturbed and horizontal. However, several partial cycles of erosion ensued after the period of uplift, and large parts of the formation were removed, the amounts eroded varying from place to place.

4 Bryan, Kirk, and Smith, G. E. P., Geology and water resources of San Pedro Valley, Ariz.: U. S. Geol. Survey Water-Supply Paper - (in preparation). 
The two localities lie on opposite sides of San Pedro River about 12 miles apart but at similar altitudes. The beds at both are horizontal and, except for evidence of minor faulting in those near Benson, apparently undisturbed. A thickness of about 250 feet is exposed in this part of the valley, but the total thickness of the formation is much greater, as shown by the logs of wells in the vicinity. The fossil-bearing layers are somewhat above the middle of the eroded section and are hence near the top of the formation. The stratified beds of these localities consist principally of red clays, sands, and soft limestones that were evidently laid down in salt lakes of small extent in the central part of the Pliocene basin.

The bones occur for the most part in relatively small patches or layers of greenish tuffaceous clay, which, according to Bryan, interfinger on one side with arkosic gravel and conglomerate typical of deposition on alluvial slopes and on the other with the lake beds. This position seems to confirm Bryan's view that these bone-bearing patches of greenish clay represent the marginal and fresh-water springs that are characteristic of the borders of salt lakes in such basins. The localities thus probably constituted the chief watering places for the animals of the region, and here, naturally, occur their fossil remains.

That these areas were once boggy water holes is supported by the condition and arrangement of the bones they contain. For example, the skull of one of the mastodons was found completely covered by the undisturbed original matrix and lying in a horizontal position resting on the lower jaws, but the top portion of the skull was crushed and eroded and the tips of the tusks reaching to the same level were broken. This damage had evidently been done while the skull yet lay partly buried in wet mud. Also the left fore leg of this animal was found in nearly normal position relative to the skull, but with the toes directed downward, reaching a level in the clay 2 feet below it. This position indicates that the animal came to his death by being hopelessly bogged. The position and arrangement of the other bones as found suggest that they had been moved about by being more or less trampled and disturbed by contemporary animals who were so fortunate as to escape being engulfed in the soft and sticky mud. A foot of each of the other two mastodons collected was found in a like position, giving additional evidence of boggy conditions. The carapace of Glyptotherium showed evidence of trampling. The top had been caved in before being completely covered and may have been thus crushed by the foot of a Stegomastodon arizonae while lying partly buried.

If, then, we accept Bryan's view regarding the conditions of deposition, it is plainly evident that the accumulation of material in the central portion of the
San Pedro basin must have taken place comparatively slowly, as these lakes, to become thus saline, must have required long periods of desiccation. The few inches to 2 feet of soft limestone that marks their former existence must therefore represent a very considerable length of time, at least a few thousand years. The springs that were marginal to the lakes must have had similar periods of existence.

Under these conditions it is quite possible that, although the general process of sedimentation in the San Pedro basin was continuous, the marginal springs of the two localities may have belonged to lakes of slightly different levels. Thus the time interval between the active existence of the watering places on the west side of the salt lakes at the Benson locality and those on the east side of the lakes at Curtis Flats may well have been long.

During this interval the faunas changed, but it does not necessarily follow that this change was greatly affected by evolution in this locality, for, although considered long as measured in years, the interval was probably in a geologic sense relatively short, and it may well be that the entire change was accomplished by migration. In fact, a comparison of the faunas seems to confirm this supposition. For example, the species of mastodon found at the Curtis Flats can not be a descendant of the one found at the Benson locality, as it belongs to a very different phylum. The Equidae, the Carnivora, the Rodentia, and, in fact, the species in general found in one locality present nothing indicating their derivation from their relatives of the other locality. In other words, though many of the species of the Curtis Flats locality are closely related to species found in the Benson locality, the former are not descendant forms of the latter.

\section{DESCRIPTIONS OF SPECIES}

\section{Order PROBOSCIDEA}

Two distinct phyla of mastodons, referable to two or possibly three new species, appear in the collections from the San Pedro Valley. One phylum, represented by a single specimen found in the locality just south of Benson, belongs to the group of mastodons with tusks possessing a band of enamel and of the nearly straight, twisted variety; the other is represented by three specimens from the Curtis Flats locality.

\section{Genus ANANCUS Aymard}

Genotype.-Anancus avernensis (Crozet and Jobert). This genus is based on an Old World species which is characterized by long, nearly straight, twisted, and enamel-banded tusks and by the fact that the third molars have five and one-half cross lophs. The Benson specimen seems to belong to this genus, but the third molars have only four cross lophs. 
Anancus bensonensis Gidley, n. sp.

\section{Plate XXXII}

Type.-The greater part of the basal portion of a skull from the posterior nareal opening forward, including the orbital and zygomatic region, and portions of the squamosal and paraoccipital of one side. The cheek teeth, except right $\mathrm{m}^{2}$, and part of the alveolar sockets of the tusks are also preserved. Part of this specimen was obtained through exchange from the University of Arizona, and parts were collected by Bryan and Gidley.

Type locality.-About $21 / 2$ miles south of Benson, Ariz., in sec. 22 , T. 17 S., R. $20 \mathrm{E}$.

Horizon.-Middle or upper Pliocene.

Diagnosis.-Molars brachyodont, semibunodont; $\mathrm{m}^{2}$ trilophodont, $\mathrm{m}^{3}$ tetralophodont with small heel; main cusps of upper molars wearing to trefoil pattern in both rows, but this pattern appears earlier and is better defined in the cusps of the inner side; lophs relatively low and set at right angles to the long axis of the tooth crown; valleys shallow and almost completely blocked medially by the accessory buttresses of the inner row of cusps; rostrum long, very broad, and but little bent down on the plane of the palate, being nearly continuous in direction with it, and seemingly correlated with the possession of nearly straight tusks; palate rather broad and but slightly arched.

The following are additional features which may be considered more or less distinctive. The posterior nares is relatively small and is oblong-elliptical in cross section, and its anterior wall slopes forward and upward from the nareal notch at an angle of about $45^{\circ}$. The glenoid surface is relatively broad antero-posteriorly, and its borders are not sharply defined. This surface is characteristically proboscidean in being slightly concave transversely and convex antero-posteriorly. In the Benson mastodon, as in Mastodon americanum, there is a transverse sulcus formed behind the glenoid surface by a broad transverse expansion of the paraoccipital. This sulcus, however, is much shallower and narrower than in the Pleistocene species, because the paraoccipital is more closely appressed to the glenoid portion of the squamosal. This feature denotes a shortening of the skull in this region and seems to affect the position of the external auditory meatus, which is situated directly above or slightly forward from the middle of the glenoid surface. In the Indiana mastodon this opening is situated distinctly farther backward and is also placed higher above the glenoid surface. The zygomatic process of the squamosal is relatively very short, and its anterior articular border rises abruptly at a much greater angle than in $M$. americanum. The orbit is relatively high above the tooth row and is placed well forward, its anterior border being directly above the anterior border of $\mathrm{m}^{2}$. The infraorbital foramen is large and is placed high upon the face as compared with this foramen in $M$. americanum. Also the maxillary border of the orbit rises abruptly at the point where it meets the jugal, indicating that there still remained in this species a well-defined inferior postorbital process.

Another striking peculiarity of the Benson species is the fact that in connection with the broad and remarkably long rostrum the anterior extremities of the premaxillaries are greatly thickened. A similar thickening of the premaxillaries may be observed in old individuals of the present-day African elephant.

In the present confused state of our knowledge of the diversified species of mastodons, it is most difficult to define accurately the limits of the several genera that have been proposed. In consequence it has long been recognized that a thorough revision of the group of Proboscidea would be most desirable. I have not attempted such a revision in connection with my present study, for this important and much needed work is already nearing completion under the able direction and personal studies of Prof. Henry Fairfield Osborn, and the present reference of the species here described to Anancus may therefore be considered only provisional. In this connection it should also be noted that the type of $A$. bensonensis seems to combine characters of species usually regarded as belonging to quite distinct genera. In Anancus avernensis of Europe, in the South American species "Mastodon andium," and in "Tetralophodon shepardi edensis," a California species recently described by Childs Frick, the tusks are apparently of the long, nearly straight type, are set rather widely apart, are but slightly divergent in the skull, and apparently have a downward turn as they emerge from the alveoli; but whether or not in Anancus bensonensis, they were twisted and possessed a band of enamel, as in the three species just mentioned, is not known. ${ }^{5}$ From the form and length of the rostrum it seems reasonable to infer that the Benson species was possessed of lower jaws of the elongate and probably tusked type, but this inference can not be verified until lower jaws have been found.

\footnotetext{
${ }^{5}$ Since writing the above description I have again visited the San Pedro Valley, where I made a second collection of fossil vertebrates, this time for the American Museum of Natural History. Among other specimens obtained is a mutilated tusk from the Benson locality. This tusk seems with little question to belong to the species of mastodon here described. If so, it entirely corroborates the statement made above, for it is sufficiently well preserved to show that it was about 4 feet long and about 4 inches in diameter and that it is of the nearly straight, twisted variety and possesses a wide band of enamel extending along nearly its entire length. This tusk was found at approximately the same level as that from which the type specimen was taken and only a few hundred feet distant from it. Its form agrees exactly with that of the alveolusin the type of Anancus bensonensis. In this connection it may be noted that in the same bed at a somewhat lower level, only a few feet away from the tusk just described, was another tusk of quite different character giving positive evidence of a second type of mastodon belonging to the Benson phases. This one, however, was too badly shattered and displaced to be preserved, but it showed by the natural mold left in the matrix which had surrounded it that it was of the short, thick, much curved, and rapidly tapering variety; also; there was no evidence of an enamel band. Two juvenile tusks from these beds, now in the American Museum of Natural History collection, give further evidence of two types of mastodons in the Benson locality. One of these is about 10 inches long and about $1 \frac{1}{2}$ inches in diameter and possessses a well-developed enamel band; the other is somewhat larger, is more curved, and has no enamel band.
} 
A specimen from the California locality in the American Museum of Natural History (No. 24047) has been referred to "Tetralophodon" edensis. This specimen has the anterior portion of the rostrum preserved, with portions of nearly straight, twisted, and enamel-banded tusks in place. It has thickened premaxillaries, as in Anancus bensonensis, but this thickening is markedly less pronounced, and the rostrum is relatively shorter.

Comparative measurements indicate that Anancus bensonensis is larger than either the South American or the California species and is further distinguished from the latter by important differences, especially in the last upper molar. $\mathrm{M}^{3}$ of the Benson species has the same number of lophs, but it is relatively longer crowned, and the transverse crests are parallel instead of outwardly diverging, as in the California species. The lophs are also less elevated, and the valleys are more open; also, there is a well-developed cingulum on the inner border of the crown, and the fourth transverse loph, instead of being small, as in "Tetralophodon" edensis, is nearly as broad and prominent as the third loph. The molars of T.edensis are described as having no cingula.

\section{Measurements of type skull of Anancus bensonensis}

[Catalog No. 10538, U. S. National Museum]

Length of $\mathrm{m}^{2}$

Millirneters

Width of $\mathrm{m}^{2}$ (measured at middle loph) _._._._._._. 88.5

Length of $\mathrm{m}^{3} \ldots$

Width of $\mathrm{m}^{3}$ (measured at second loph)__._._._. 99.0

Diameter of tusk (estimated from alveolus) _........ 130. 0

Basal length of skull from postnareal notch forward... 815. 0

Greatest width of palate (between posterior lophs of second molars)

Narrowest point of palate (between posterior lophs of last molar)

76. 0

Distance from $\mathrm{m}^{2}$ to anterior end premaxillary _....... 460.0

Extension of maxillary anterior to $\mathrm{m}^{2}$

Width of skull at orbit (computed)

Width of rostrum at narrowest point (estimated) _.... 550.0

Width of premaxillaries at exit of tusks (estimated) .... 640. 0

Width of premaxillaries between alveolar borders of

tusks_._. _ _ _ _

Vertical diameter of premaxillaries at anterior extremity - 125. 0

Vertical diameter of orbit_._._._.

\section{Genus STEgomastodon Pohlig}

The genus Stegomastodon was proposed by $\mathrm{H}$. Pohlig in $1912^{6}$ and was based on the species Mastodon mirificus Leidy.

The generic position of the species described below, founded on materials from the Curtis Flats locality, can be assumed with much more confidence than that of the Benson species just described. Its general characteristics, which include a short, narrow, spoutlike symphysis of the lower jaw and the reduction of the dental series in each jaw to a single six or seven

6 Soc. belge géologie Bull., vol. 26, p. 193, 1912. lobed bunodont molar in the older adult stage, mark it rather definitely as belonging to the group typified by Stegomastodon mirificus (Leidy). Although only the characters of the lower jaw are known from the type, a nearly complete skull and lower jaws from the Blanco formation of Texas, now in the American Museum of Natural History, has been referred by Osborn to this group, and a comparison of this specimen seems to confirm the generic reference of the Curtis Flats specimens, although their specific rank appears to be quite distinct.

\section{Stegomastodon arizonae Gidley, n. sp.}

\section{Plates XXXIII-XXXIX}

Type.-Portion of skeleton of a young adult male, including the base portion of the skull with tusks and cheek teeth in place; the lower jaws; both fore limbs (one with nearly complete foot); parts of both hind limbs; the pelvis; and several of the more characteristic vertebrae and ribs (catalog No. 10707, U. S. National Museum).

Referred material.-(1) Portions of a skeleton of a moderately old male, including the basal portion of the skull with teeth and tusks in place; the lower jaws; a fore limb and foot lacking only the proximal end of the humerus and the greater portion of the scapular blade; a few ribs and vertebrae; and the sacrum with parts of the pelvis (catalog No. 10556, U. S. National Museum). Found at about the same level as the type specimen, and about 100 yards distant. (2) A complete hind foot and distal end of tibia associated with a lower jaw lacking teeth (cata$\log$ No. 10917, U. S. National Museum). Found about 50 feet from No. 10556 and at the same level.

Type locality.-Curtis Flats, about 14 miles southeast of Benson, Ariz., in sec. 25, T. 18 S., R. $21 \mathrm{E}$.

Diagnosis.-Skull short; rostrum short and bent sharply downward on the plane of the palate; lower jaws with short symphysis, spoutlike chin and no tusks; a single tooth in each jaw in old individuals, as in Stegomastodon mirificus (Leidy); tusks without enamel, large, stout, much curved, and widely spreading so that at the point of exit from the skull they diverge at right angles to each other; second molars when present, tetralophodont, or nearly so; third molars sextalophodont or septalophodont, with heel; lophs when unworn relatively high, with summits of main cusps closely approached, leaving the shallow longitudinal median valley nearly closed; principal cusps of the last lower molar not arranged in straight lines antero-posteriorly, as in most species of mastodons, but curving outward posteriorly, giving to the tooth crown a twisted appearance.

The cusps of these molars, above and below, arise one above the other in the jaw, so that the anterior 
lobes, appearing much earlier, are deeply worn before the more posterior ones come into use. These last two are progressive characters which parallel or are rather tending toward the condition of tooth replacement found in the true elephants and which mark this species of mastodon as having advanced, at least in this respect, much beyond the better-known later survivor of this great group of Proboscidea, Mastodon americanum. The tendency toward elephantlike development of the last molars of Stegomastodon arizonae is an important difference to be noted in comparing it with $S$. mirificus, the latter being a less progressive species. In $S$. mirificus the summits of the lophs are more nearly on the same plane and are more evenly worn by use, as in Mastodon americanum. This progressive feature is also strongly marked in certain species of Old World mastodons and is likewise present, but to a much less degree, in certain other American species, as Megabelodon lulli Osborn and Tetrabelodon campester Cope.

Comparative measurements of Stegomastodon and Mastodon, in millimeters

Teeth, skulls, and jaws

Length of $\mathrm{m}^{2}$

Width of $\mathrm{m}^{2}$

Width of $\mathrm{m}^{3}$ at second loph

Length of $\mathrm{m}_{2}$

Length of $m_{3}$.

Width of $m_{3}$ at second loph

Diameter of tusk (greatest)

Diameter of tusk (least) at same point

Basal length of skull from condylar notch

Length of $\mathrm{m}^{2}$ to anterior end premaxillaries

Length of palatal notch to end premaxillaries

Width of skull at orbits

Width at exit of tusks

Width at narrowest point of rostrum

Width of maxillaries at posterior end of tooth ro

Width of palate at narrowest point

Width of palate at widest point

Length of lower jaw, condyle to symphysis

Length from angle to point of symphysis

Length from cheek-tooth row to point of symp

Depth of jaw at condyle.

Depth of jaw at coronoid process

Depth of jaw at anterior end of $\mathrm{m}^{3}$

Antero-posterior diameter of symphysis

Vertical diameter of symphysis.

\begin{tabular}{|c|c|c|c|}
\hline \multicolumn{2}{|c|}{ Stegomastodon arizonae } & \multirow{2}{*}{$\begin{array}{l}\text { Mastodon } \\
\text { americanum, } \\
\text { aged adult } \\
\text { (catalog No. } \\
\text { 8204) }\end{array}$} & \multirow{2}{*}{$\begin{array}{c}\text { Stegomastodon } \\
\text { mirificus, type, } \\
\text { aged adult } \\
\text { (catalog No. } \\
\text { 209) }\end{array}$} \\
\hline $\begin{array}{c}\text { Type, } \\
\text { young adult } \\
\text { (catalog No. } \\
\text { 10707) }\end{array}$ & $\begin{array}{c}\text { Referred, } \\
\text { aged adult } \\
\text { (catalog No. } \\
\text { 10556) }\end{array}$ & & \\
\hline 95 & & 119 & \\
\hline $\begin{array}{r}86 \\
212\end{array}$ & 260 & $\begin{array}{r}90 \\
185\end{array}$ & \\
\hline 97 & 87 & 95 & \\
\hline 110 & & 120 & \\
\hline $\begin{array}{r}92 \\
230\end{array}$ & $25 \overline{8}$ & $\begin{array}{r}90 \\
180\end{array}$ & 210 \\
\hline 98 & 77 & 102 & 76 \\
\hline 160 & 192 & 205 & -.- \\
\hline 128 & 162 & 205 & -- \\
\hline 820 & 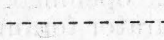 & 1,045 & $\cdots+-1$ \\
\hline $\begin{array}{l}300+ \\
580\end{array}$ & & $\begin{array}{l}405 \\
760\end{array}$ & 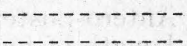 \\
\hline 605 & & 745 & (n) \\
\hline 600 & 500 & 185 & $\ldots \ldots$ \\
\hline 340 & 400 & 525 & $\ldots \ldots$ \\
\hline 230 & 260 & 300 & $\ldots \ldots$ \\
\hline 49 & $\begin{array}{l}85 \\
08\end{array}$ & $\begin{array}{l}107 \\
185\end{array}$ & $n^{-n-12 n-1}$ \\
\hline $\begin{array}{r}70 \\
740\end{array}$ & $\begin{array}{r}98 \\
800\end{array}$ & $\begin{array}{l}185 \\
965\end{array}$ & 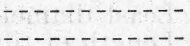 \\
\hline 662 & 670 & 750 & $\ldots \ldots$ \\
\hline 200 & 210 & 250 & 220 \\
\hline 345 & 410 & 515 & $-1-1-2-1-2-1$ \\
\hline $\begin{array}{l}300 \\
150\end{array}$ & $\begin{array}{l}335 \\
200\end{array}$ & $\begin{array}{l}445 \\
201\end{array}$ & $1-2-1)^{-2-2}$ \\
\hline 140 & 121 & 155 & 73 \\
\hline 75 & 121 & 125 & 70 \\
\hline
\end{tabular}

Length of cervical series

Length of dorsal series

Length of lumbar series

Length of sacral series

Length of

centrum of first dorsal.

Length of centrum of second dorsal

Length of centrum of first lumbar

Height of anterior dorsal spines, first.

Height of anterior dorsal spines, second

Height of anterior dorsal spines, third

Height of anterior dorsal spines, fourth

Length of scapula, glenoid cavity to top

Distance from top to posterior angle of blade

Distance from spine to posterior angle of blade

Distance from spine to anterior angle of blade

Length of metacromion.

Antero-posterior diameter at constriction below spine

$$
\text { - Restored. }
$$

\begin{tabular}{|c|c|c|}
\hline \multicolumn{2}{|c|}{ Stegomastodon arizenae } & \multirow{2}{*}{$\begin{array}{l}\text { Mastodon } \\
\text { americanum } \\
\text { (catalog No. } \\
\text { 8204) }\end{array}$} \\
\hline $\begin{array}{l}\text { Type (catalog } \\
\text { No. 10707) }\end{array}$ & $\begin{array}{l}\text { Referred (catalog } \\
\text { No. 10556) }\end{array}$ & \\
\hline a 1,450 & & 480 \\
\hline 1, 445 & & 1,650 \\
\hline 250 & & 360 \\
\hline $\begin{array}{l}b 350 \\
0\end{array}$ & $c 285$ & ${ }^{b} 363$ \\
\hline $\begin{array}{r}2,030 \\
45\end{array}$ & $x^{-1-2-2}$ & $\begin{array}{r}2,490 \\
70\end{array}$ \\
\hline 55 & & 80 \\
\hline 75 & & 80 \\
\hline 225 & & 405 \\
\hline 385 & $\cdots$ & 550 \\
\hline $\begin{array}{l}420 \\
425\end{array}$ & $\cdots$ & $\begin{array}{l}550 \\
520\end{array}$ \\
\hline $\begin{array}{l}425 \\
765\end{array}$ & 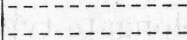 & 920 \\
\hline 780 & & 910 \\
\hline 512 & 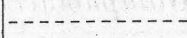 & 510 \\
\hline $\begin{array}{l}150 \\
285\end{array}$ & 315 & $\begin{array}{l}150 \\
365\end{array}$ \\
\hline 230 & $\quad 235$ & 230 \\
\hline
\end{tabular}

- 3 vertebrae. 
Comparative measurements of Stegomastodon and Mastodon, in millimeters-Continued

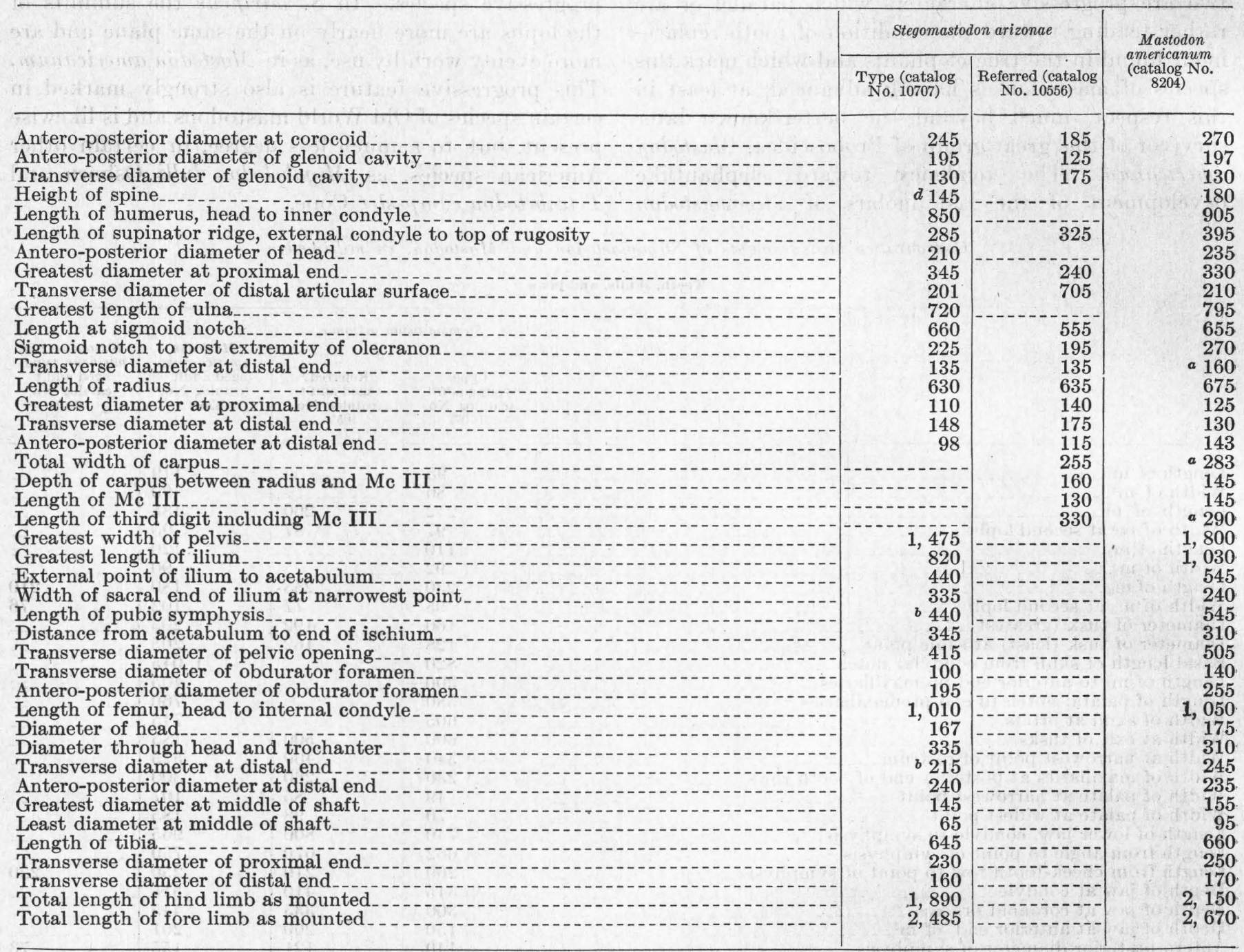

a Cast from the "Warren" mastodon skeleton mounted in the American Museum of Natural History, New York City, substituted in the National Museum mount. b Estimated.

Additional skull and skeleton characters.-Stegomastodon arizonae is typically proboscidean throughout in skull and skeleton characters, as might be expected, and in many respects, therefore, it resembles Mastodon americanum. ${ }^{7}$ Certain important modifications, however, may be noted, which clearly distinguish it from this type of mastodon and also from the Gomphotherium group in so far as the osteologic characters of that group are known.

The skull, above a plane passing through the base of the orbits and the upper border of the condyles, is wanting, but the portion preserved, which includes the jugal of the left side and carries the cheek teeth and both tusks in place, indicates clearly that it is not of the elongate type, like that of Mastodon americanum and Gomphotherium, but is much more brachyo-

${ }^{7}$ For convenience, most of the comparisons are made with the nearly complete skeleton of the Indiana mastodon, a male $M$. americanum, now on exhibition in the National Museum (catalog No. 8204), which is essentially like the "Warren" mastodon now mounted in the American Museum of Natural History, well known through published descriptions. cephalic than either. In addition the tusks are relatively short, much curved, and widely divergent; the rostrum is short, broad, and bent sharply downward. immediately in front of the cheek teeth, much as in the elephants; and the palatal region in the type skull is very narrow and little or not at all arched.

The lower jaws are moderately long but have a. short, deep symphysis with narrow, spoutlike chin and no tusks.

The scapula is much like that of $M$. americanum, being readily distinguished from the Elephas type: by the relatively broader proportions of its posterior blade. The metacromion is a long, well-developed process, as in $M$. americanum, extending backward. from the lower half of the spine to form a wide Vshaped valley with the likewise well-developed acromion. Compared with the Indiana specimen this valley is shallower and the metacromion is less downwardly directed, being nearly at right angles. with the scapular spine. 
The humerus is of about the same robust proportions as that of the Indiana mastodon but differs from it in some important respects. The deltoid ridge seems to be relatively thinner and higher, is less rugose, and is extended distally considerably farther along the shaft. Likewise the supinator ridge, although relatively shorter and less salient in its prominent rugose distal portion, extends its proximally diminishing portion much farther up the shaft. Thus the ends of these two prominent ridges overlap each other for a much greater distance than in the Indiana mastodon and in consequence form a conspicuous longitudinal external sulcus, which in the Indiana specimen is not present or but weakly defined. Also the internal condylar ridge in the Arizona species is more prominent and more backwardly extended. Compared with that of $M$. andium, the humerus is relatively robust, and it agrees rather closely in general proportions with that of Gomphotherium angustidens. Of seemingly less importance is the fact that the relative length of the rugose portion of the supinator ridge in $S$. arizonae is but little less than one-third the total length of the humerus; in $M$. americanum it is definitely more than one-third this length; in $G$. angustidens it is shortest, being definitely less than one-third; and in $M$. andium it is longest, being nearly one-half the total length of the humerus.

The ulna differs from that of the Indiana specimen in that the olecranon process is relatively very short. This seems to be characteristic also of the true elephants. The radius is much like that of $M$. americanum and seems to differ only in that the head is more expanded antero-internally and narrows up to a greater degree externally, thus making it more definitely triangular in cross section.

The fore foot is in general much like that of $M$. americanum but is somewhat more slender in proportions. The carpus and metacarpal III are about equal in length. In $M$. americanum the carpus exceeds the length of metacarpal III, and the phalanges are relatively longer.

The pelvis differs from that of $M$. americanum in having the anterior border of the ilium more convexly curved in outline, viewed from behind, and the upper or sacral portion is more expanded anteroposteriorly. The pubic symphysis is long, as in $M$. americanum, but its posterior region seems to be not so robust nor so conspicuously produced backward and downward as in that species. The uncertainty of this statement is due to the fact that this portion of the pelvis is somewhat crushed and damaged. Crushing also prevents an accurate and detailed comparison of the femur and tibia, but these bones have about the same general proportions and modifications as those of $M$. americanum.

The left astragalus is all that was found to represent the hind feet of the type specimen, but there is in the collection a nearly complete hind foot of another specimen (No. 10917) associated with a portion of a lower jaw showing the alveolus for a single cheek tooth, which seems to warrant its reference to this species. This foot was found with the bones all articulated, nearly in their normal position but so firmly cemented together that they can not be separated for detailed study. The general characteristics, however, can be clearly made out. The tarsal elements are relatively thick compared with those of the Indiana mastodon, hence the tarsus as a whole is longer and narrower than that of $M$. americanum. The toes, on the contrary, are relatively short, and the lateral pair, D I and D V, have the phalanges much reduced, those on D I being apparently represented by a single shapeless nodule of bone. The terminal phalanges of the other toes are also apparently wanting.

Comparative measurements of the hind feet of Stegomastodon arizonae and Mastodon americanum, ${ }^{a}$ in millimeters

\begin{tabular}{|c|c|c|}
\hline & $\begin{array}{c}\text { Stego- } \\
\text { mastodon } \\
\text { arizonae } \\
\text { (catalog } \\
\text { No. 10917) }\end{array}$ & $\begin{array}{c}\text { Mastodon } \\
\text { americanum } \\
\text { (catalog } \\
\text { No. 8204) }\end{array}$ \\
\hline Transverse width of calcaneum.- & 165 & 175 \\
\hline Antero-posterior diameter at distal end. & 135 & 130 \\
\hline Transverse width of astragalus (tibial face) & 130 & 130 \\
\hline Thickness at anterior face & 50 & 40 \\
\hline Transverse width of navicular & 150 & 155 \\
\hline Thickness at anterior face & 46 & 29 \\
\hline Transverse width of external cuneiform & 71 & 90 \\
\hline Thickness at anterior face & 52 & 3 \\
\hline Transverse width of metatarsal III (proxi- & & \\
\hline $\begin{array}{l}\text { mal end) } \\
\text { Length of metatarsal III }\end{array}$ & $\begin{array}{r}74 \\
100\end{array}$ & $\begin{array}{r}75 \\
110\end{array}$ \\
\hline Total length of digit III & 145 & 205 \\
\hline Vertical thickness of tarsus at digit III. & 165 & 143 \\
\hline Total width of tarsus & 315 & 350 \\
\hline
\end{tabular}

a Part of this foot of the Indiana mastodon is restored by using casts of the bones of the "Warren" mastodon now on exhibition in the American Museum of Natural History, New York City.

Although the axial skeleton of the type is by no means complete, its general characters are rather clearly indicated by several typical vertebrae and ribs. Portions of the first four dorsal vertebrae, including the spines, the last two dorsals, the three lumbars, the sacrum, and the anterior two caudals, are preserved. Many of the ribs are represented by pieces of various completeness. These taken together are sufficient to form a fairly accurate basis for restoration of the body portion of the skeleton, which seems to correspond in general with that of the Indiana mastodon, although certain differences of detail may be noted. In the Indiana specimen the spine of the first dorsal approaches in height those of the second and third, which are equal and the highest of the series. In the Arizona specimen the fourth dorsal spine is the highest, the second is next, the third a little shorter, and the first still shorter, being relatively much shorter than the corresponding one of the Indiana mastodon. 
Specimen No. 10556, provisionally referred to Stegomastodon arizonae (p. 86), in so far as the corresponding portions preserved will permit comparison, seems to present the principal characteristics distinctive of the species. It differs from the type, however, in certain important details. These may be briefly stated as follows: (1) It represents a larger individual (see table of comparative measurements, p. 87); (2) the cheek teeth are reduced to a single one $\left(\mathrm{m}^{3}\right)$ in each jaw; (3) $\mathrm{m}^{3}$, both upper and lower, is relatively and actually narrower than that of the type, and, although much worn, indicates clearly that the homologous lophs are relatively less elevated and the valleys correspondingly less open; (4) the tusks are notably larger and less cylindrical, being subquadrate in cross section; (5) the symphysis of the lower jaw is deeper; and (6) the palate is deeply arched and about twice the width of that of the type skull.

Such differences as these, if found at all constant where abundant material is available, would unquestionably be considered as indicating two distinct species. In the present instance, however, only two specimens can be compared, and I am therefore inclined to consider most of these differences, at least, as due to individual variations and age changes, both of which are generally recognized as being considerable in most species of proboscideans. Although both specimens are adult, the paratype was evidently a much older individual, and to this fact may be attributed, for example, its generally larger proportions and the more advanced stage of development of the cheek teeth. It does not, however, account for the smaller size and different proportions of the teeth, nor would it seem to explain entirely the great difference in width and form of the palate, although this modification would doubtless be very considerably affected by it. The type is a young adult, yet it had reached the stage in which the limb bones and most of the vertebrae had entirely closed the sutures of their epiphyses. Although the second molars are worn nearly to the roots and were about to be shed, the hinder molars had not yet fully emerged from the jaw bone, and only the anterior loph of each is worn to any degree. In the referred specimen the anterior molars have entirely disappeared and the last molars had emerged to their full height in the jaws, yet in these only the two anterior lophs are deeply worn, the third is moderately worn, and the fourth is just beginning to show signs of wear. As both specimens seem to be of the same sex (male), sex variation need not be considered in this comparison.

General features of the skeleton as mounted.-In addition to the characteristics pointed out in the above detailed description, a few features worthy of note are presented in the general skeletal structure of Stegomastodon arizonae as restored and mounted. The general proportions of the skeleton are in part conjectural. However, the length of the back, computed from the few characteristic vertebrae preserved, and the definitely known features of the skull indicate rather clearly that $S$. arizonae was relatively higher and shorter than Ifastodon americanum; both the pelvis and the skull are more elephantlike in general form, but the tusks are much more divergent than is usual in any proboscidean.

Two characteristic features relative to the fore limbs in the Proboscidea were very clearly brought out in the mounting of both this specimen and the skeleton of the Indiana mastodon. One concerns the proper location of the shoulder joint; the other relates to the normal position of the elbow joint. In seeking to determine where to place the scapulohumeral joint, it was observed that the second rib to a greater degree and the third to a less degree were bowed inward just above mid-section, and that the first rib was also depressed on its posterior border in the same region. Thus there is formed a broad, shallow depression in the anterior-superior rib structure, which obviously can be for no other purpose than to accommodate or give room for the limited play of the heavy shoulder joint. The skeletons of living species of elephants examined show a like structure; hence it may be assumed to be characteristic of the Proboscidea in general. To follow up this idea, several skeletons of the larger, heavier ungulates were examined, and most of them were found to show a similar but usually less distinct depressed area. Its position, however, is not the same in the ungulates as in the Proboscidea, being lower and more anterior, so that its center comes between the first and second ribs and near their distal ends. This difierence in position seems to be correlated with the greater angulation of the shoulder and elbow joints in the ungulates.

In determining the normal position of the elbow joint, it was found in articulating the bones of the fore leg that by placing the fore foot in a normal position-that is, rather well under the body-the elbow joint was brought around to a position in which its transverse axis was directed at a very oblique angle to the transverse axis of the body, and thus the anterior planes of these joints face obliquely inward, instead of nearly directly forward, as in most ungulates. This also seems to be a distinctly proboscidean feature and is apparently a purely mechanical adaptation necessitated by the great weight and bulk of the creature. An observer watching an elephant walk will note that the fore foot, as it leaves the ground and is started forward for the next step, is well to the outside of the perpendicular longitudinal plane of the body; hence, in order to take the weight of the body again on coming to the ground, it is carried forward and obliquely inward across this plane. The opposite fore leg, swinging inward and forward in its turn, gives 
the peculiar side to side swaying motion of the shoulders as the animal moves forward. Thus the fore legs of proboscideans do not move directly forward in a straight walk but swing in an inward-directed oblique plane; hence the obliquity of the elbow joint when placed in a normal position.

\section{Order EDENTATA}

\section{Suborder GLYPTODONTIA}

The existence of glyptodonts in the United States was first made known by Cope, who in 1888 described one-half of a single scute of the carapace as the type of a new species, Glyptodon petaliferus. ${ }^{8}$ In the next several years other fragments of glyptodonts were discovered and described, but nothing of importance came to light until 1903, when an American Museum expedition discovered in the Blanco (Pliocene) formation of western Texas a partial skeleton consisting of a nearly complete carapace, a pelvis, a sacrum, a caudal series, and a complete tail armature. This material was described by Osborn, who made it the basis of a new genus and species, Glyptotherium texanum. ${ }^{9} \quad$ Next followed Brown's description of some good specimens from Mexico, discovered in part by himself and in part by other collectors at a much earlier date. On this combined material he founded the new genus Brachyostracon. ${ }^{10}$ Brown states that the earlier collections mentioned, consisting of two nearly complete carapaces of glyptodonts, were discovered near Tequixquiac. One of these is preserved in the Mexican National Museum of Natural History, the other in the National School of Engineers in Mexico City. The former was described in 1874 by Señores J. N. Cuatáparo and Santiago Ramírez, who gave it the name Glyptodon mexicanus. This material was mentioned by Dr. Marino Barcena in 1882, by Cope in 1884, and again by Dr. Manuel M. Villada in 1903 (see Brown's article for references). Villada gave a faulty drawing of the carapace in the Natural History Museum. The descriptions given by these authors were very inadequate; hence our first real knowledge of the Mexican glyptodonts came through Brown's contribution, just cited. The next important contribution is that of Hay, ${ }^{11}$ who in 1917 described a specimen (catalog No. 6071, U. S. N. M.) from supposed Pleistocene deposits in Wolf County, Tex. This specimen includes several characteristic parts of the carapace and skeleton. Hay referred it to Cope's species Glyptodon petaliferus, and compared it in detail with the South American species Glyptodon asper Burmeister, to which he considered it generically related.

Thus up to the present time only four valid species, representing three genera of glyptodonts, have been

${ }^{8}$ Am. Naturalist, vol. 22, p. $345,1888$.

9 Osborn, H. F., Am. Mus. Nat. Hist. Bull., vol. 19, pp. 491-494, 1903.

${ }_{10}$ Brown, Barnum, Am. Mus. Nat. Hist. Bull., vol. 31 , pp. 167-177, pls. 13-18, 1912.

11 Hay, O. P., U. S. Nat. Mus. Proc., vol. 51, pp. 107-116, pls. 3-5, 1917. reported from North American localities. Two of these species came from Mexico, the other two from the United States. Now, a fifth species, represented by good material, has been discovered in the Curtis Flats locality of the San Pedro Valley and is here described. This species seems to belong to the genus Glyptotherium as defined by Osborn.

\section{Genus GLYPTOTHERIUM Osborn}

Genotype-Glyptotherium texanum Osborn, from the Blanco (Pliocene) formation of western Texas.

This genus is characterized by a relatively elongate carapace, simple tail structure, and relatively primitive carapace plates, which are arranged in more or less regular lateral rows extending over the back and of which the central areas are distinctly larger than the peripheral ones in all parts of the carapace. Another characteristic of this genus, given by Brown for Glyptotherium texanum and verified in a specimen of $G$. arizonae from the Curtis Flats locality collected in 1924 for the American Museum of Natural History, is that the pubes are reduced to thin rods of bone.

Glyptotherium arizonae Gidley, n. sp.

\section{Plates XL-XLIV}

Type.-Part of a skeleton, including the lower jaws; complete limbs and feet of the right side; a section of the back bone; portions of the carapace, including the nearly complete border of the right side; and various detached scutes of the carapace and tail rings (catalog No. 10536, U. S. National Museum).

Paratypes.-Nearly complete tail piece, including vertebrae and bony rings, and hinder lower border portions of the carapace of both sides (catalog No. 10537, U. S. National Museum); the greater part of the carapace with a few teeth and foot bones associated (catalog No. 10336).

Type locality.-About 3 miles east of the Curtis ranch, in sec. 25 , T. 18 S., R. 21 E., Cochise County, Ariz., about 10 feet above and 100 feet distant from locality of the type of Stegomastodon arizonae.

Horizon.-Upper Pliocene deposits.

Diagnosis. - Size large, length of carapace about 1,700 millimeters ( 5 feet 8 inches) measured over curve of back, total length of animal about 2,285 millimeters ( 7 feet 7 inches); carapace elongate, with a small area of imbricated and more or less movable scutes bordering its anterior lateral margins; plates in all parts of the carapace, with central areas definitely larger than those of the periphery; carapace plates with depressed centers except those of the first, second, and parts of the third and fourth marginal rows; tail comprising twelve vertebrae and ten chevrons; tail armature with eight movable rings and a terminal cone composed of three closely sutured rings; tail armature and postero-lateral carapace plates moderately ornate. 
Skull not known. Lower jaws deep, with massive, spoutlike symphysis, lower border nearly semicircular in outline, and ascending ramus relatively broad and directed well forward; cheek teeth all three-lobed, but the anterior two are not completely molariform, and the third from the front is more elongate than those posterior to it. Hind feet short and wide, with five subequal digits; fore feet short, with digit I vestigial or wanting, digits II and III subequal, constituting a stout, conspicuous pair, and digits IV and V much reduced.

Detailed description.-The dentition is represented by the complete lower series of the type and a few upper teeth associated with paratype No. 10336. It presents certain modifications which seem to be characteristic of the species. These teeth resemble

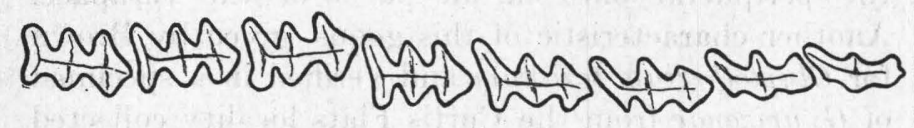

FIGURE 4.-Glyptotherium arizonae Gidley. Type. Lower cheek teeth of left side, one-half natural size.

in general form and proportions those of the South American glyptodonts, but differ in that the lobes of the molariform teeth are more oblique, their extremities are more angular, and the posterior face of the lower molars and anterior face of the upper are slightly indented by a shallow longitudinal sulcus. This gives a concave outline to the posterior lobes of the lower teeth and to the anterior lobes of the upper. In all other species of glyptodonts, so far as known, the posterior face of the lower cheek teeth is more or less convex. In general proportions the teeth of G. arizonae are like those of the South American genus Glyptodon, but they are more nearly like those of Hoplophorus ornatus (=Lomaphorus ornatus, fide Lydekker) as figured by Burmeister ${ }^{12}$ in that they are relatively narrow and loosely. spaced. In degree of specialization the anterior three teeth are rather intermediate between the more simple ones of Hoplophorus and the more completely molariform ones of Glyptodon.

Other features to be noted in the lower dentition of the Arizona species are the conspicuous prolongation of the posterior external angle, especially of the first four teeth, and the relatively great width of the anterior lobe in the hinder molars. Thus in the last four teeth of the series the anterior lobes exceed in width the middle lobes, and in all but the last one of the group the midlobe is exceeded in width by the posterior lobe also.

Of the elements of the vertebral column of this species anterior to the caudal region, only the dorsal tube is known. This is composed of ten fused vertebrae, as in Panochthus. According to Burmeister

${ }_{12}$ Museo público de Buenos Aires Anales, vol. 2, pl. 19, figs. 2, 3, 1874.
Glyptodon has eleven vertebrae included in this tube and Hoplophorus has twelve.

The caudal vertebrae are twelve in number and, like the tail armature, more nearly resemble those of G. texanus than they do any of the South American forms. They differ from those of the Texas species in that the processes of the anterior ones are relatively longer in the same proportion that the anterior rings are larger.

Both scapulae are well preserved in the type specimen and show some distinctive characteristics. As this element is not known in any other of the North American species, it can be compared only with South American forms. In general it resembles more nearly that of Glyptodon than that of Panochthus as figured by Burmeister, but it differs widely from both in its greater antero-posterior expansion and the relatively much greater extent of the rounded superior scapular border. The respective areas of the prescapular and postscapular fossae have about the same proportion to each other as in Glyptodon, but their form is quite different. In Glyptodon the prescapular fossa is ovoid in general outline, with the portion included in the suprascapular border only about one-half the extent of the prescapular border. In Glyptotherium arizonae this fossa is nearly triangular in outline, with the portion included in the suprascapular border nearly twice that of the prescapular border. The postscapular border is likewise proportionately much less extended than in Glyptodon.

The humerus of $G$. arizonae lacks the entepicondylar foramen, as in Glyptodon, but in proportion and other respects is more like that of Hoplophorus, which has this foramen well developed. Apart from the lack of the entepicondylar foramen, the humerus is distinguished from that of Hoplophorus in that both the deltoid and supinator ridges, though just as strongly developed, are less extended along the shaft. Also the bicipital groove seems to be narrower in the Arizona specimen, both supratrochlear fossae are relatively deep, and there is present in the type a welldefined supratrochlear foramen.

Like the humerus, the radius and ulna are relatively slender and more nearly resemble those of Hoplophorus than they do those of the other South American genera. The ulna especially is like that of Hoplophorus. In Glyptodon the shaft of the ulna is greatly shortened and deepened. The bones of the fore foot are peculiar only in that they are relatively very much shortened as compared with those of Hoplophorus and are nearly as robust as those of Glyptodon.

The pelvis of this species can not at present be described, although a complete one is preserved with a specimen recently collected from the Curtis Flats locality for the American Museum of Natural History. This is still in the matrix and will not be avail- 
able for description until it can be cleaned up. From my observations in the field, however, it may be stated that this pelvis has a much reduced pubis, as reported by Brown for Glyptotherium texanum. ${ }^{13}$

The femur of $G$. arizonae is very heary and massive as compared with the humerus, but like the other limb bones, it is more slender in proportions than that of Glyptodon. It differs from the femora of all the South American forms, especially in the conformation of its distal end, which is definitely offset from the median line of the shaft toward the inner side, thus making a greater obliquity to the exterior border of the supinator ridge; it differs also in a definitely greater elevation of the great trochanter, which extends above the head of the femur. The femur of $G$. petaliferus described by Hay more closely resembles that of the Arizona species than it does that of Glyptodon. This is especially true of the form and character of the distal half of the shaft, which is quite as obliquely directed. The great trochanter, however, is much less elevated.

In the Arizona species the hind foot shows some important differences both in structure and in proportions from those of South American glyptodonts. It is much broader and more robust than those of Panochthus and Hoplophorus and is less robust than that of Glyptodon. In the less reduction of the lateral toes, the hind foot of Glyptotherium arizonae is like that of Glyptodon and differs from those of Panochthus and Hoplophorus. The form and arrangement of the tarsal elements, however, seem to differ widely from those of Glyptodon as compared with the figures given by Burmeister. ${ }^{14}$ Among the most conspicuous differences to be noted are that the metatarsals in the Arizona species are proportionately long, the three cuneiforms, the cuboid, and the navicular are less widely expanded, the navicular is much less depressed in its middle anterior aspect, and the external and middle cuneiforms are entirely separated in front, owing mainly to the relatively greater elevation of the second metatarsal. Their borders come into direct contact in Glyptodon.

Although many of the modifications noted in the foregoing description of Glyptotherium arizonae may not be considered individually as distinctive, the combination of characters emphasizes the generic distinctness between the South American and North American glyptodonts.

It is not within the scope of this paper to review Hay's description of the glyptodont from northern Texas, which he referred to Glyptodon petaliferus Cope. ${ }^{15}$ It may be stated, however, that although the teeth of this Texas form are more like those of Glyptodon than those of Glyptotherium in general

\footnotetext{
${ }_{13}$ Brown, Barnum, Am. Mus. Nat. Hist. Bull., vol. 31, p. 175, 1912.

${ }_{14}$ Museo público de Buenos Aires Anales, vol. 2, pl. 36, 1874.

${ }^{15}$ Hay, O. P., U. S. Nat. Mus. Proc., vol. 51, pp. 107-116, pls. 3-5, 1916.
}

character, such resemblances, with modifications as above designated in comparing the femora (seem to apply to all the skeletal elements so far as they are known. For this reason it seems probable that the species proposed by Cope and more adequately described on more complete material by Hay may prove to belong to a new genus. The great difference in geographic situation of the Texas locality and the type locality of Glyptodon adds to this probability. It is perhaps best, however, to retain this species where Cope and Hay have left it until more is known of the carapace and tail armature and the pelvic, sacral, caudal, and dorsal structure.

Measurements of Glyptotherium arizonae (type), in millimeters

Length of animal measured in straight line, including head and tail_._.

Length of carapace measured over curvature _......... 1, 700

Greatest width of carapace measured over top_........ 2, 120

Length of tail armature

Length of caudal vertebrae series_._.

Length of proximal ring _... 83

Length of fourth ring - _._.

Length of eighth ring _._._. 105

Length of terminal cone........ 320

Vertical diameter of proximal ring _. . . . _........... 360

Vertical diameter of fourth ring _.

Vertical diameter of eighth ring

Vertical diameter of terminal cone . . . . . . . . . . . 113

Transverse diameter of first caudal _._.

Transverse diameter of fifth caudal_... . . _......... 185

Transverse diameter of ninth caudal_...... 85

Transverse diameter of twelfth caudal__._.

Length of dorsal tube _...... 465

Total length of lower jaw

Length of symphysis_._.

Length of tooth row

Depth at sixth cheek tooth

Depth at condyle_........ 245

Antero-posterior diameter of ascending ramus at tooth row

Greatest vertical depth of scapula

Greatest antero-posterior width_._._._._._._._. 443

Antero-posterior diameter of articular face_._._._._._. 83

Greatest transverse diameter of articular face_........ $\quad 40$

Length of acromion, measured on curve

Length of humerus, head to internal condyle_......... 355

Greatest diameter of head

Transverse diameter of distal articular surface

Greatest diameter of proximal end _........... 105

Greatest diameter at distal end $\ldots$

Narrowest transverse diameter of shaft_._._._._..... 40

Length of radius between articular faces . . . . . . . . . $\quad 170$

Transverse diameter of proximal end _.

Transverse diameter of distal end

Greatest length of ulna

Length of olecranon

Length of shaft sigmoid notch to distal end............ 150

Transverse width of sigmoid surface $\ldots \ldots \ldots$

Transverse width of distal articular surface

Length of carpus betweeen radius and digit III ......... 48

Length of digit III, including metacarpal_._. _....... 115

Length of terminal phalanx _.... $\quad 70$

Length of metacarpal III _._.

Greatest width of carpus . . 
Length of femur head to internal condyle.

Length of third trochanter to external condyle

Greatest diameter of head.

Transverse diameter of distal articular face

Greatest width at proximal end

Length of supinator ridge

Transverse diameter of shaft at narrowest point

Diameter of shaft at upper end of supinator ridge.......
456

496

92

130

270

221

100

165
Length of tibia

Transverse diamater of tibia and fibula, proximal end...-

Transverse diameter of tibia and fibula, distal end....... 130

Length of tarsus between tibia and metatarsal III ..... 40

Transverse width of same

Length of digit III, including metatarsal_._.

Length of metatarsal III . .

Length of terminal phalanx 


\section{PLATES XXXII-XLIV}





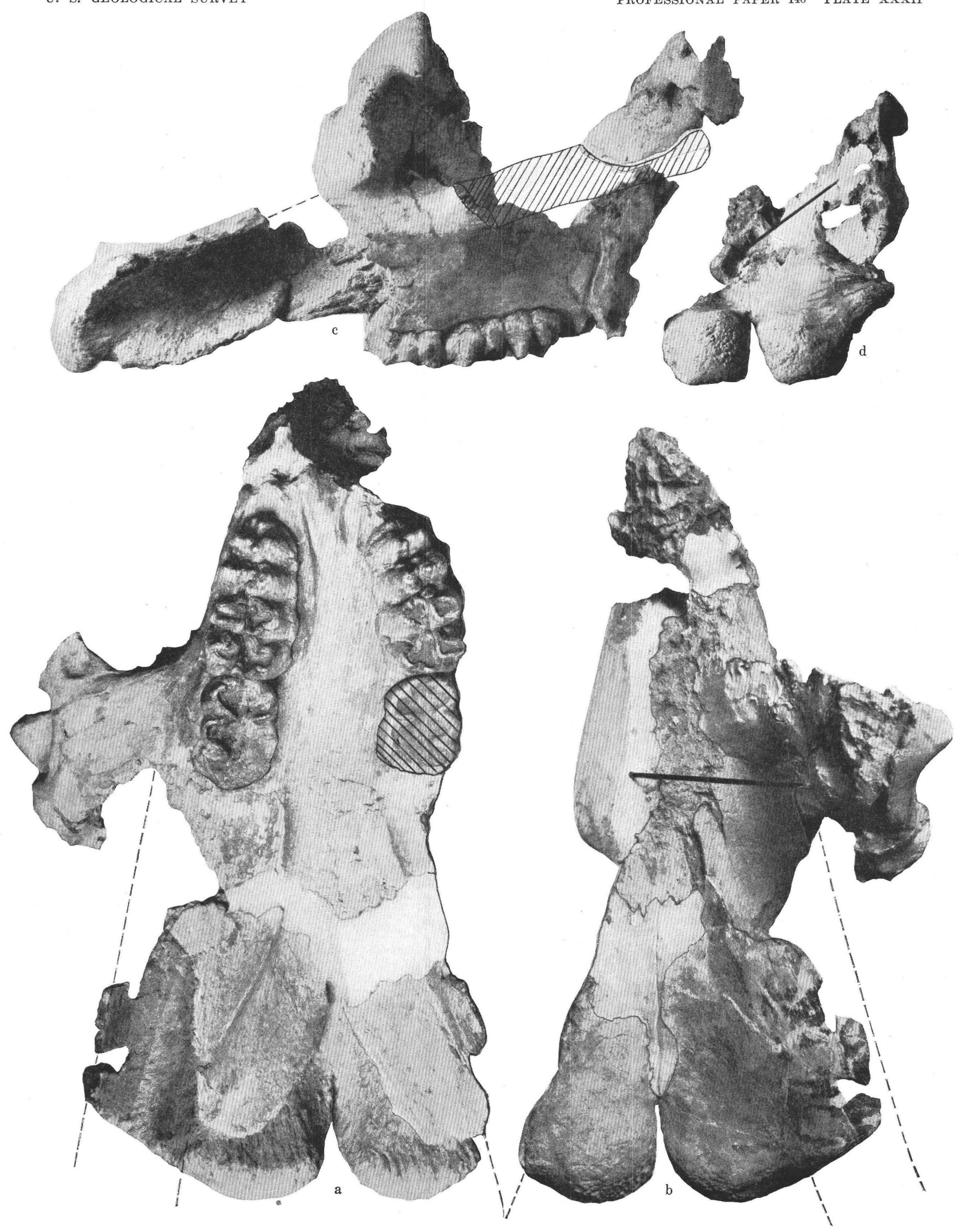

FOSSIL MAMMALS FROM SAN PEDRO VALLEY, ARIZ.

Portion of skull of Anancus bensonensis Gidley, n. sp., type (No. 10538, U. S. Nat. Mus.). a, Palate view; b, view from above; c, view from left side; d, anterior $85658^{\circ}-26-10$ view, $a, b$, c, about one-sixth natural size; $d$ much reduced 


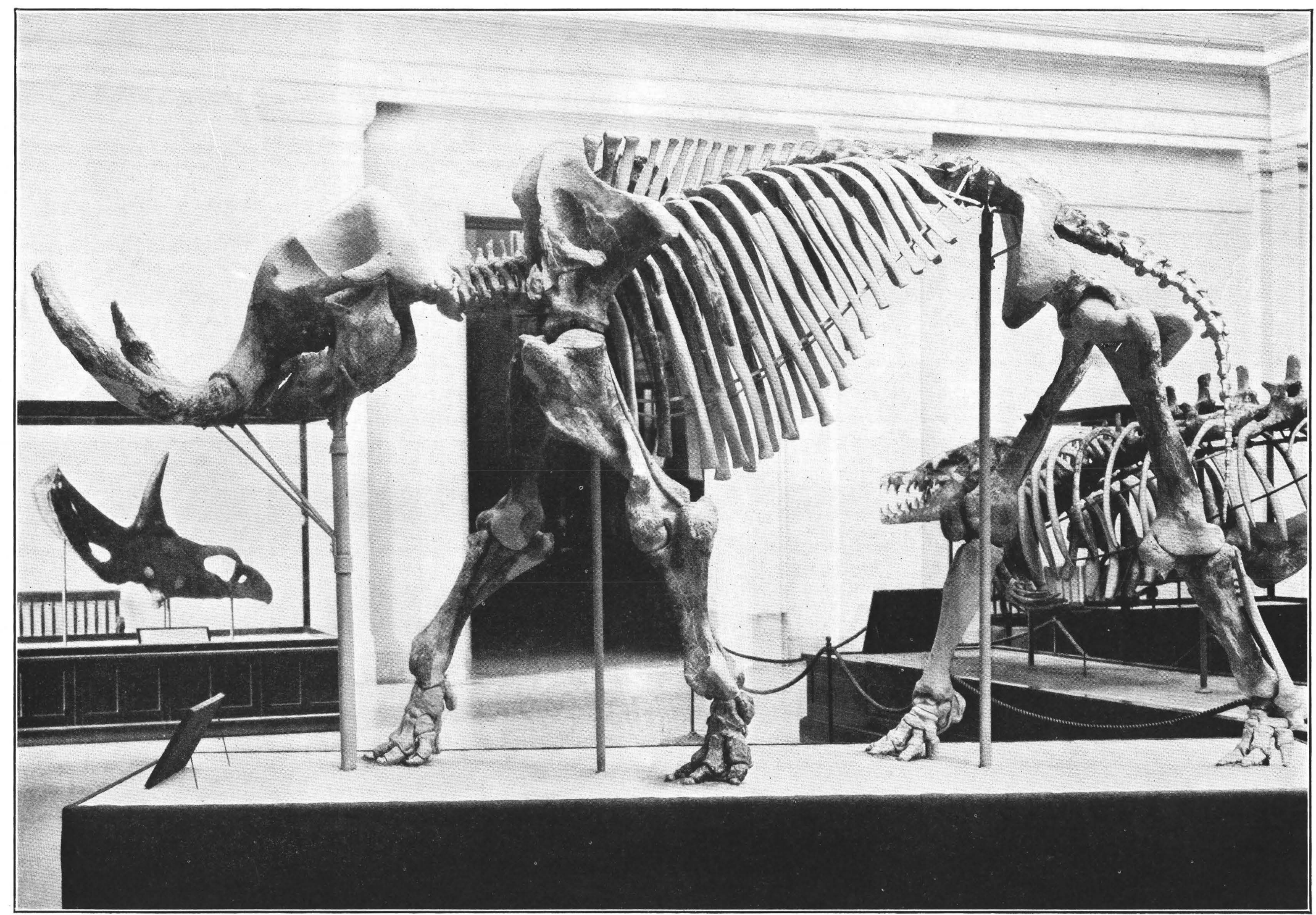


U. S. GEOLOGICAL SURVEY

PROFESSIONAL PAPER 140 PLATE XXXIV
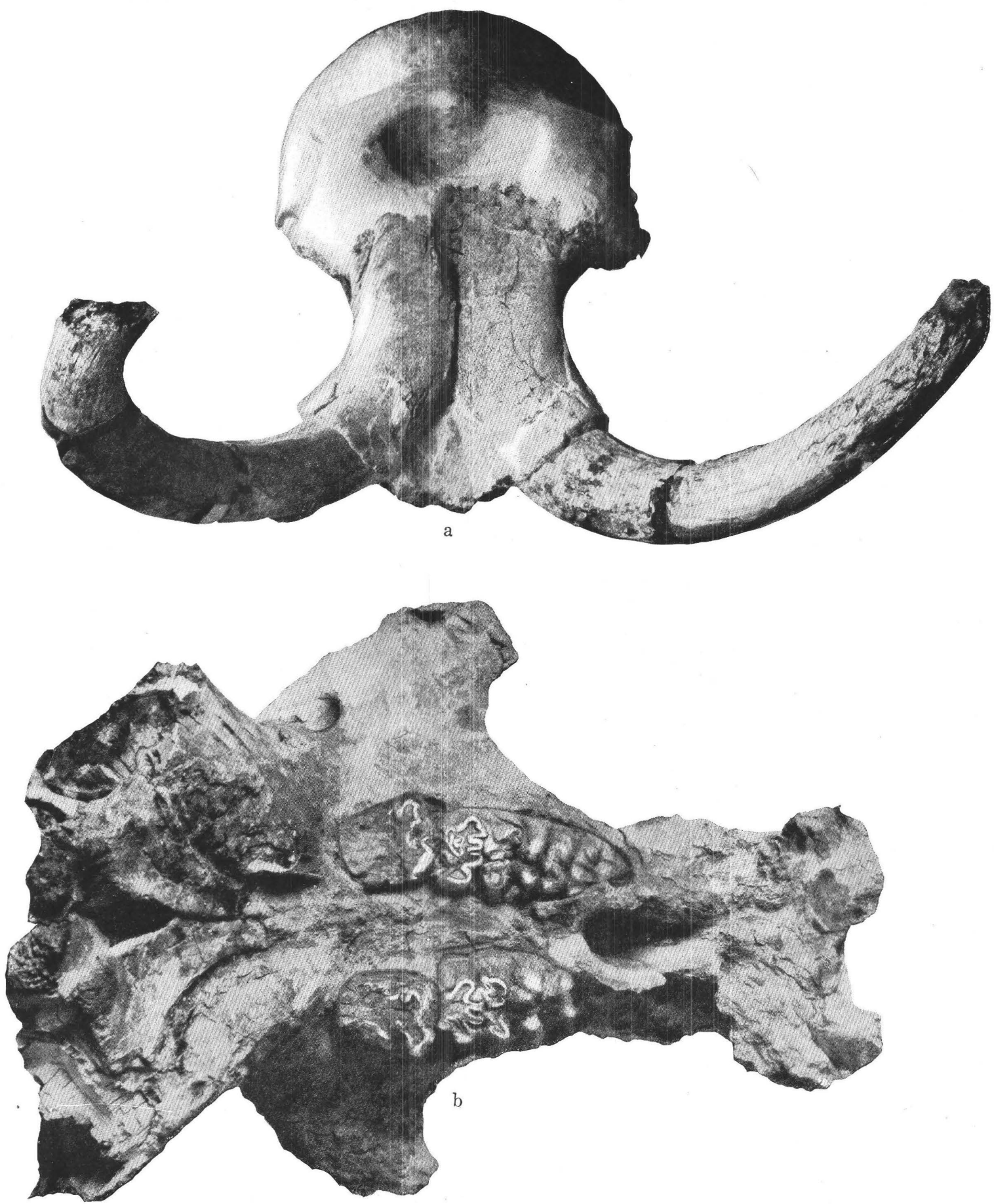

FOSSIL MAMMALS FROM SAN PEDRO VALLEY, ARIZ.

Skull of type of Stegomastodon arizonae Gidley, n. sp. (No. 10707, U. S. Nat. Mus.). About one-seventh natural size. a, Front view; b, palate view 


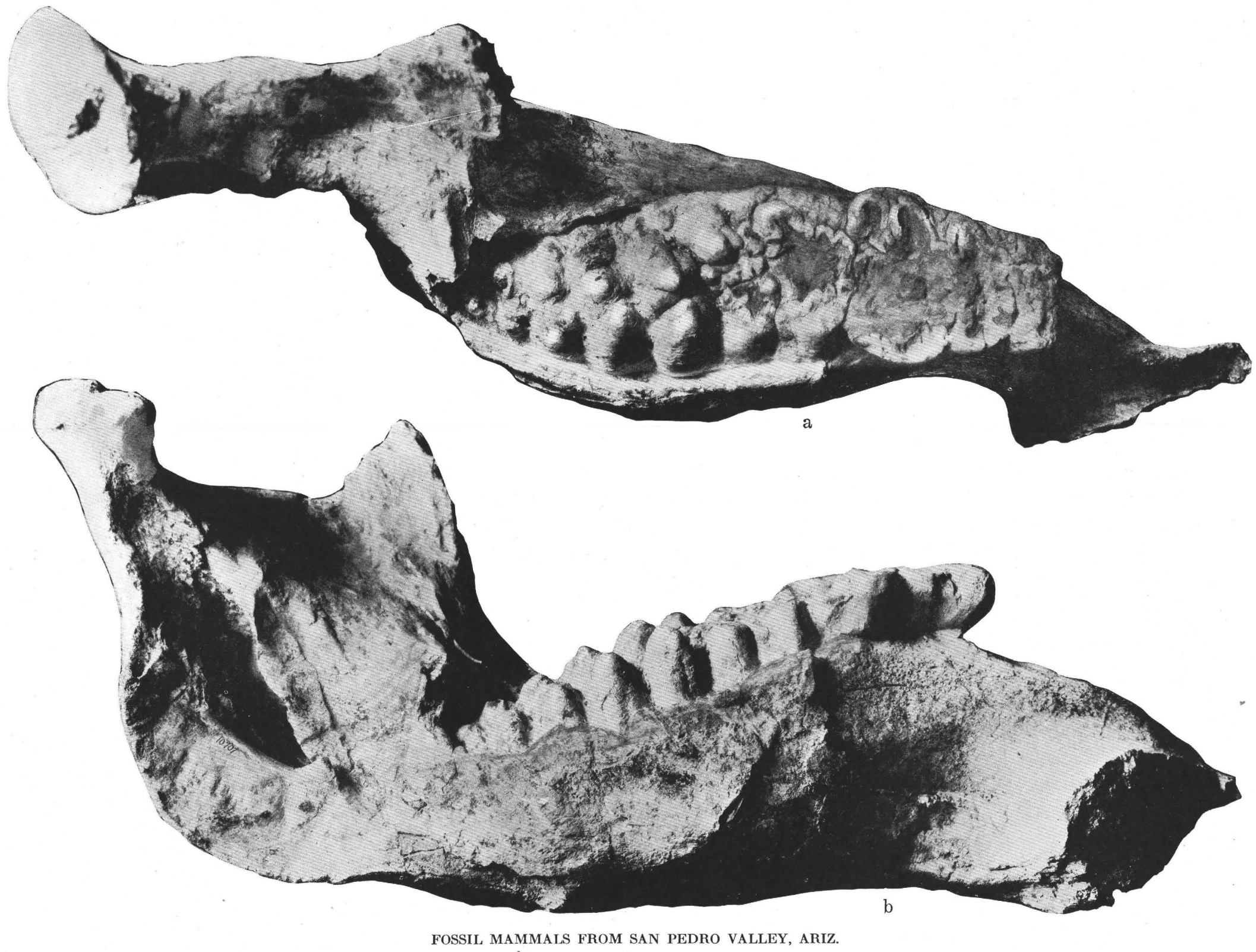

Left lower jaw of type of Stegomastodon arizonae Gidley, n. sp. (No. 10707, U. S. Nat. Mus.). About one-third natural size. a View from above; b, inner side view 

U. S. GEOLOGICAL SURVEY
PROFESSIONAL PAPER 140 PLATE XXXVI
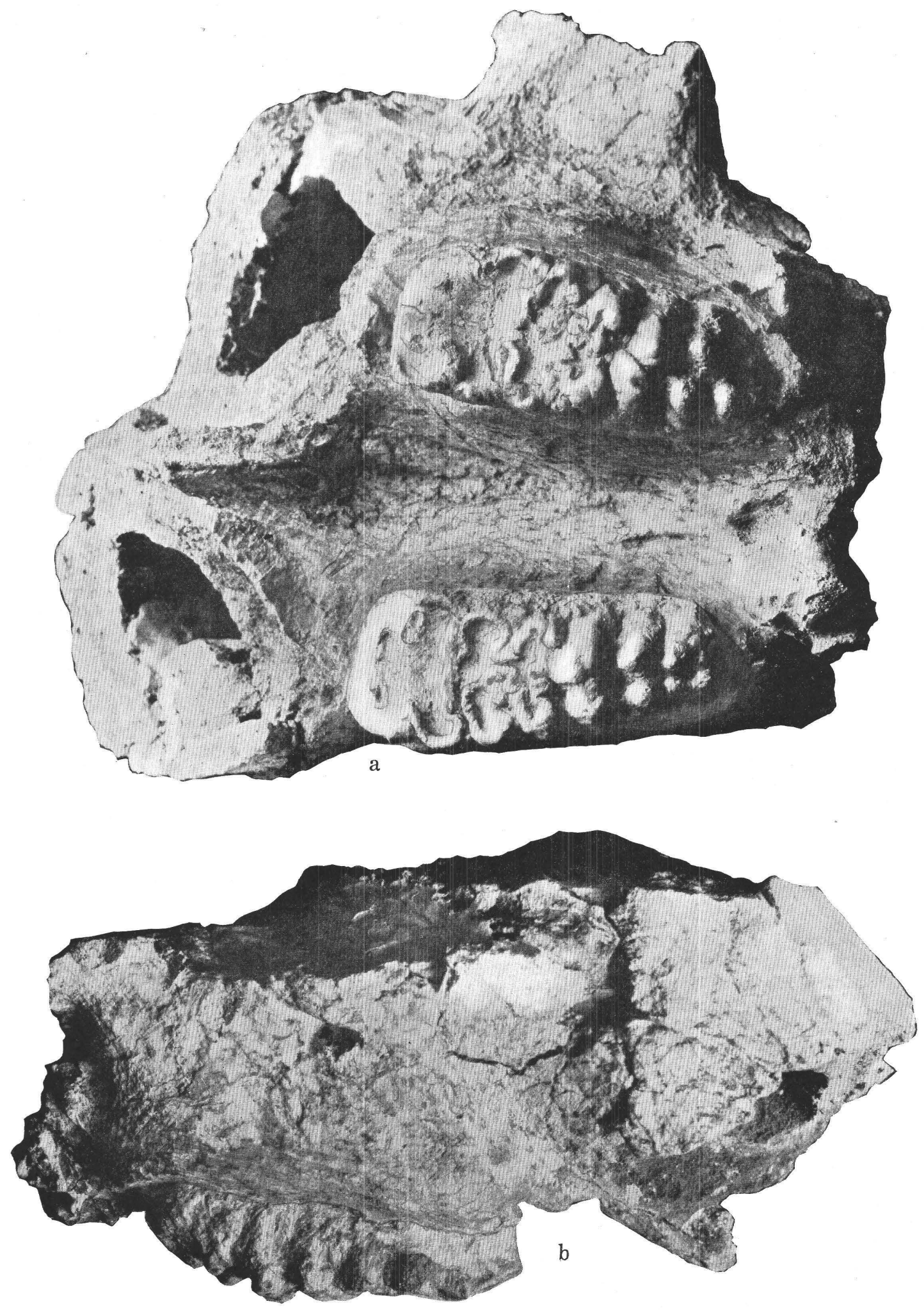

FOSSIL MAMMALS FROM SAN PEDRO VALLEY, ARIZ.

Portion of skull of Stegomastodon arizonae Gidley, n. sp. (No. 10556, U. S. Nat. Mus.). A bout two-sevenths natural size. a, Palate view; $b$, view from right side 


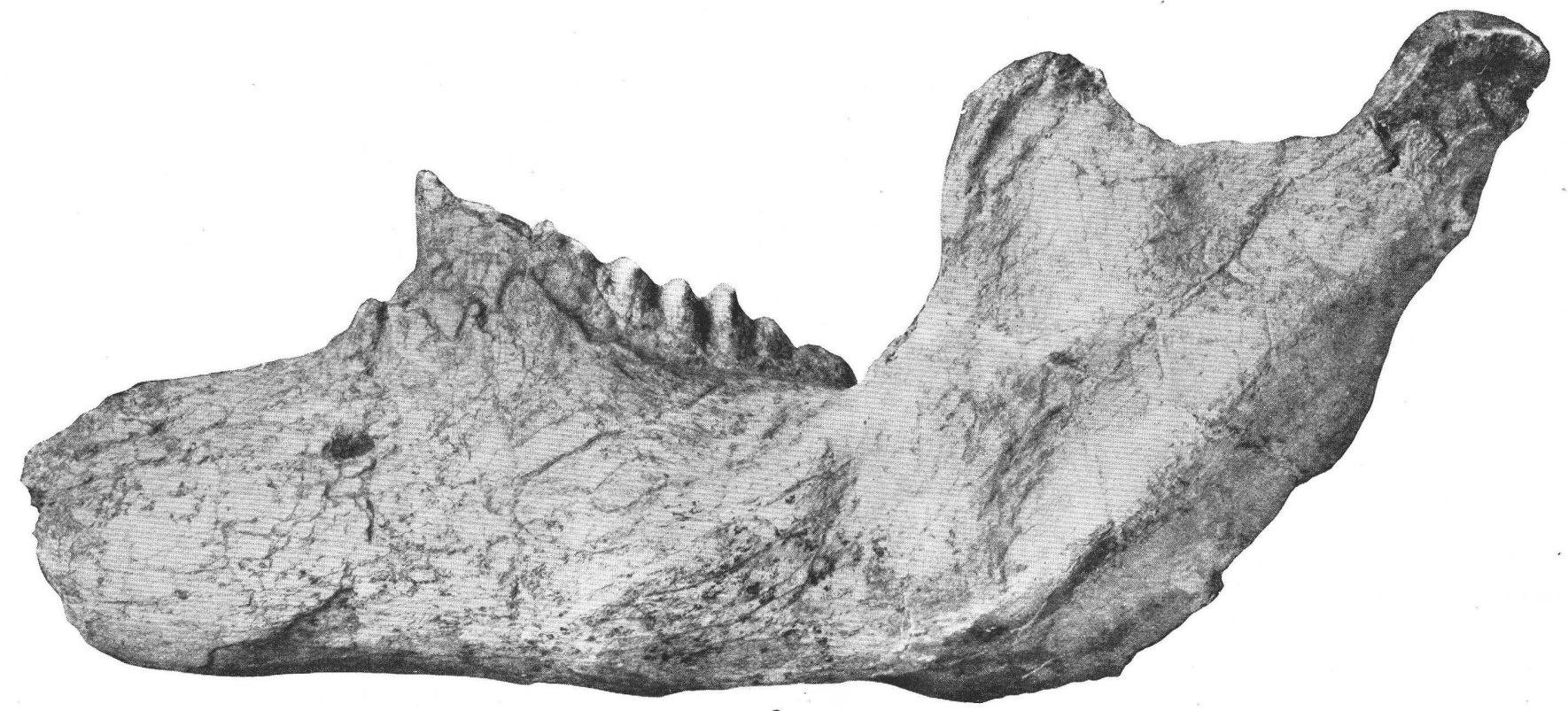

a

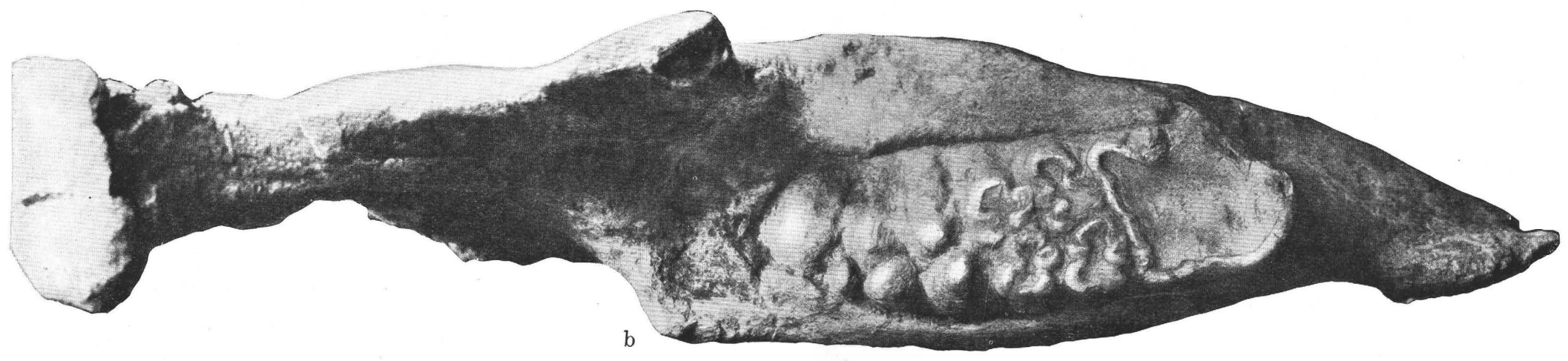

FOSSIL MAMMALS FROM SAN PEDRO VALLEY, ARIZ.

Left lower jaw of Stegomastodon arizonae Gidley, n. sp. (No. 10556, U. S. Nat. Mus.). About two-sevenths natural size. a, Outer side view; b, view from above 
U. S. geological survey
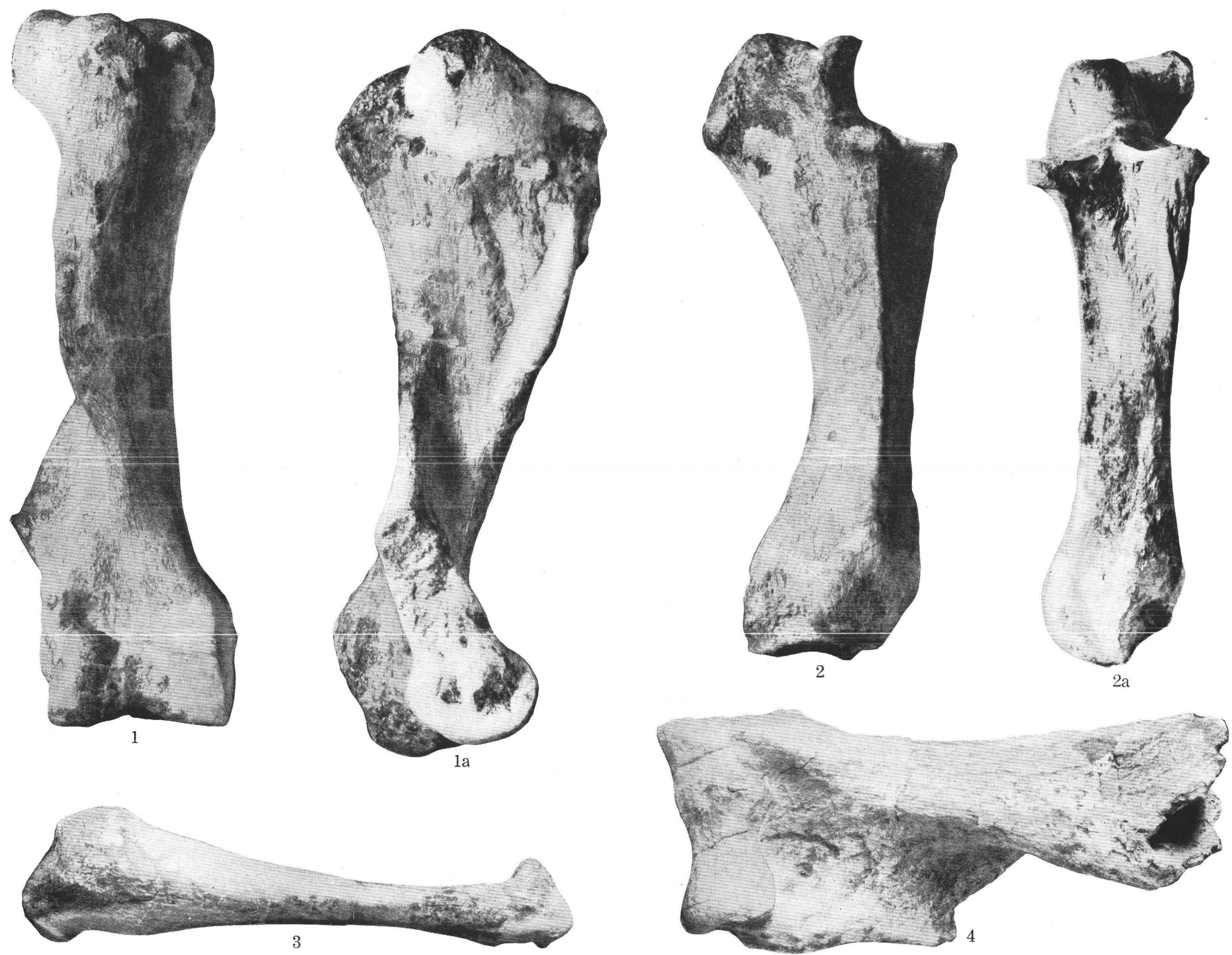

FOSSIL MAMMALS FROM SAN PEDRO VALLEY, ARIZ.

Bones of Stegomastodon arizonae Gidley, n. sp. 11 about one-sixth natural size. 1-3, Type (No. 10707, U. S. Nat. Mus.); 4, No. 10556, U. S. Nat. Mus. 1, Right humerus, anterior view; 1a, same, outer side view; , reft ulnat 

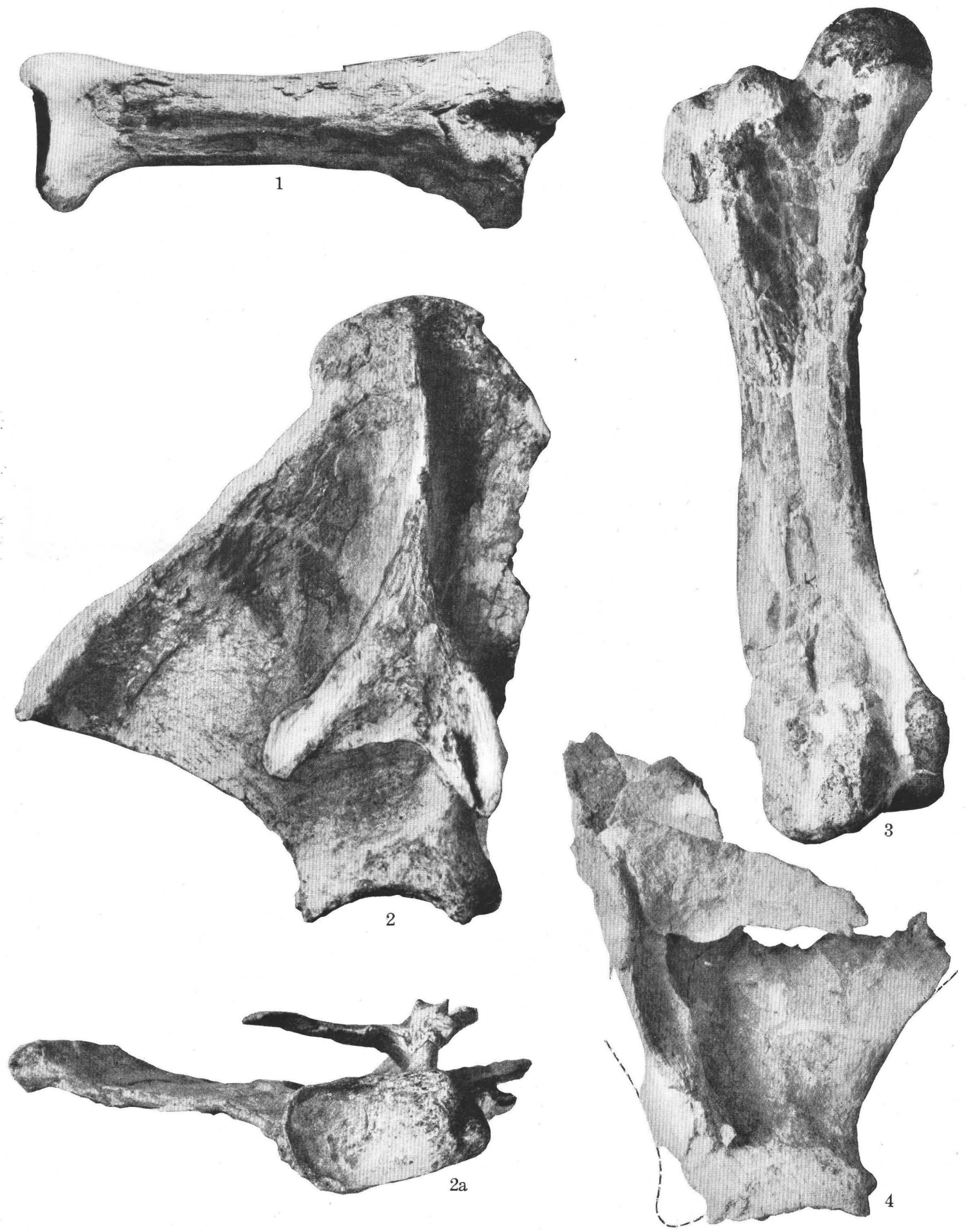

FOSSIL MAMMALS FROM SAN PEDRO VALLEY, ARIZ.

Bones oî Stegomastodon arizonae Gidley, n. sp. 1-3, Type (No. 10707, U. S. Nat. Mus.); 4, No. 10556, U. S. Nat. Mus. All about one-eighth natural size. 1, Left tibia, anterior view; 2, right scapula, outer view; 2a, same, view from below; 3 , right femur, anterior, slightly oblique view; 4 , portion of left scapula, outer view 


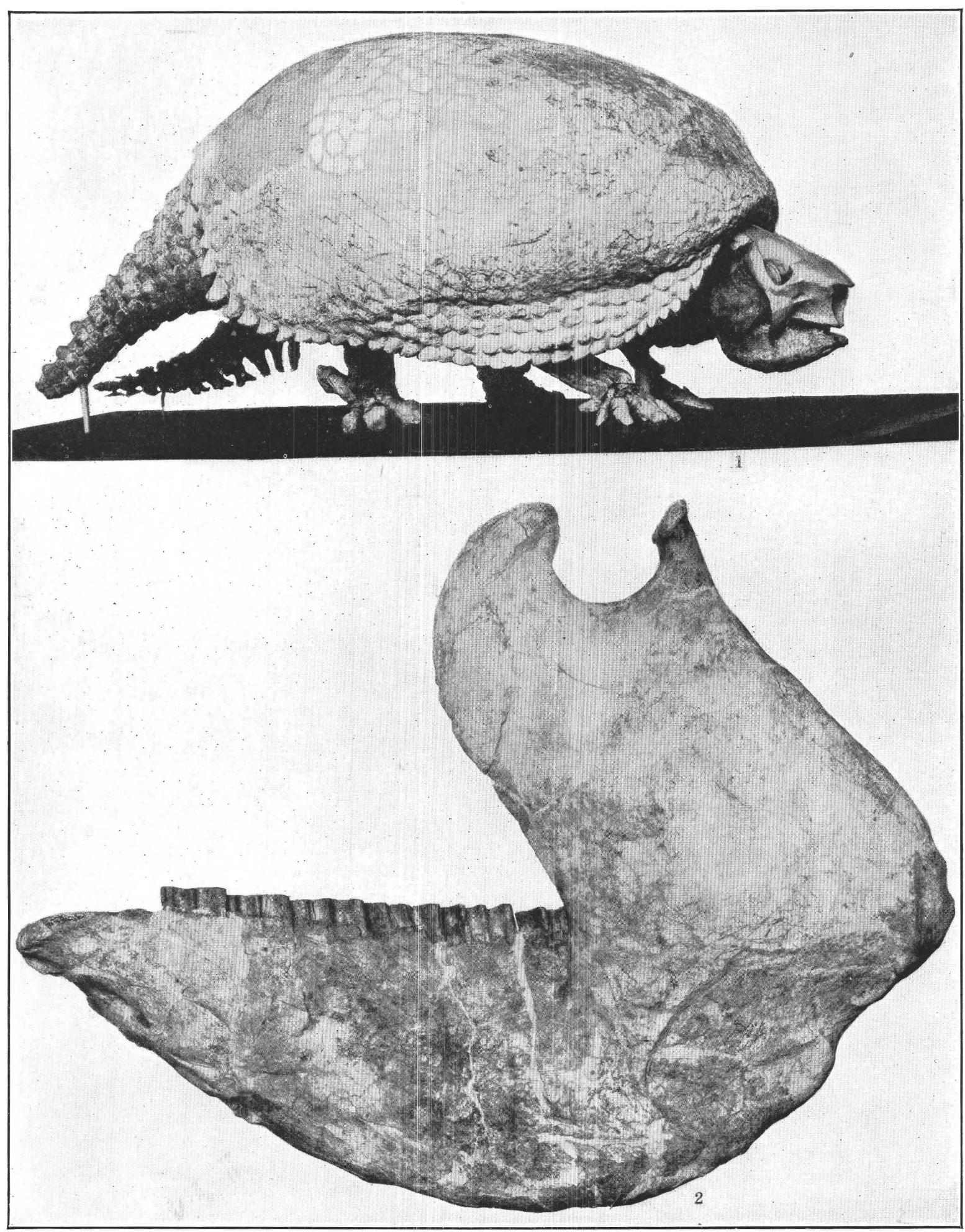

FOSSIL MAMMALS FROM SAN PEDRO VALLEY, ARIZ.

Glyptotherium arizonae Gidley, n. sp. 1, Skeleton, composite of three individuals, Nos, 10536 (type), 10537, and 10336, U. S. Nat. Mus.; about one-sixteenth natural size. 2, Left lower jaw of type (No. 10536), outer side view; about one-half natural size 
U. S. GEOLOGICAL SURVEY

PROFESSIONAL PAPER 140 PLATE XLI
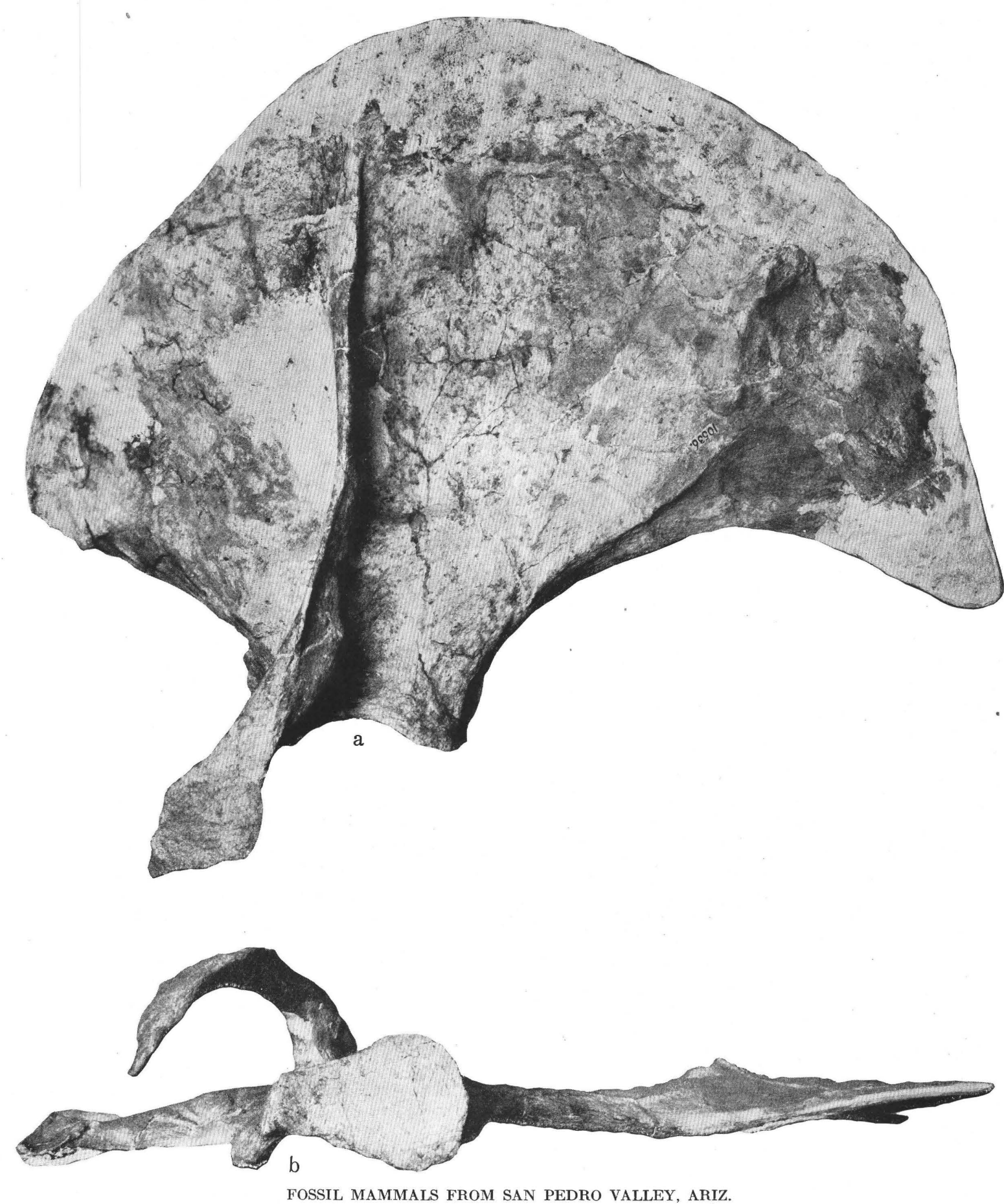

Left scapula of Glyptotherium arizonae Gidley, n. sp., type (No. 10536, U. S. Nat. Mus.). About one-third natural size. a, Outer side view; b, view from below 

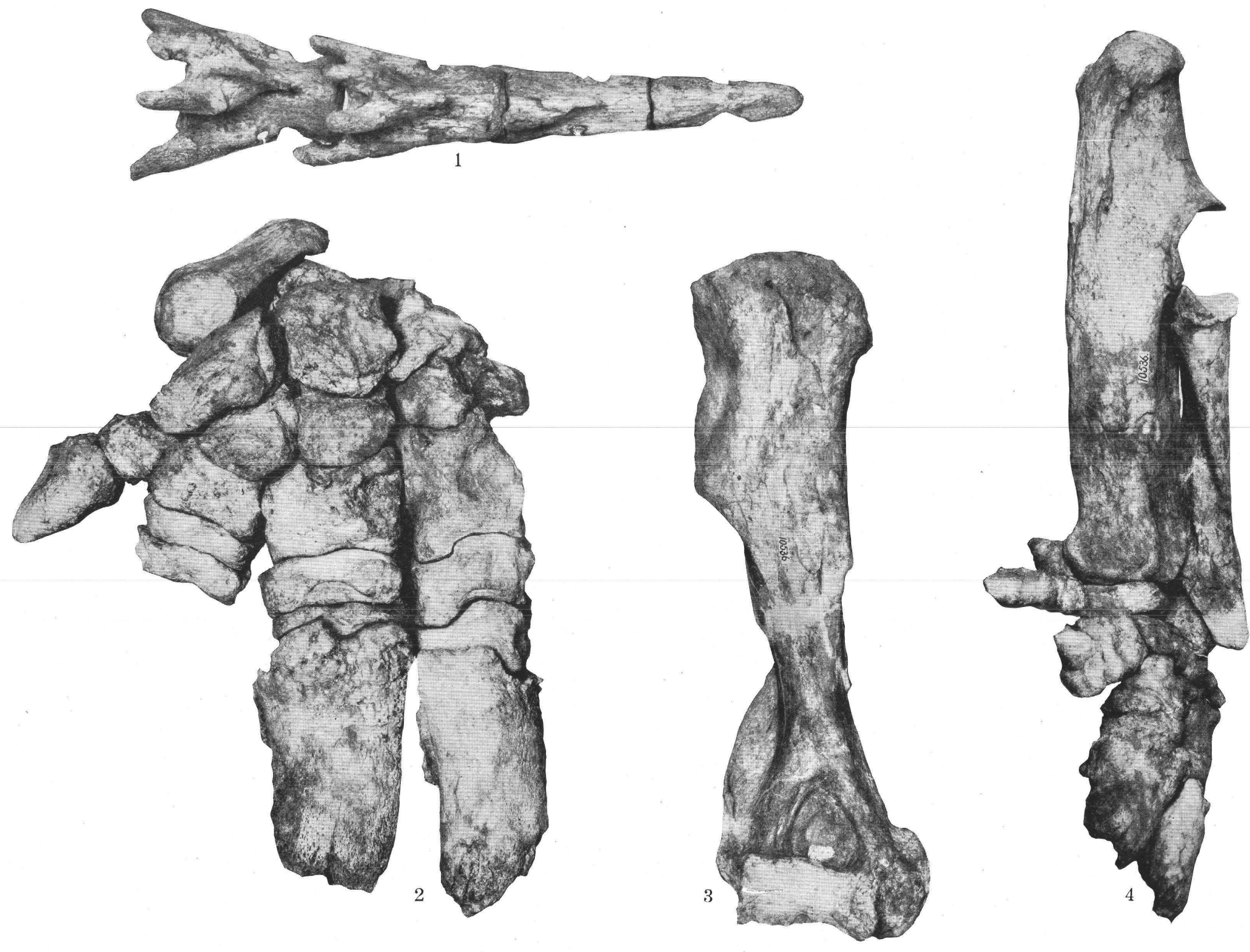

FOSSIL MAMMALS FROM SAN PEDRO VALLEY, ARIZ.

Bones of Glyptotherium arizonae Gidley, n. sp. 1, Distal four caudal vertebrae of No. 10537, dorsal view, about one-fourth natural size; 2, right fore foot of type (No. 10536), plantar. view, about one-half natural size; 3 , right humerus, anterior view, about one-third natural size; 4 , right fore arm and fore foot of type, outer side view, about one-third natural size 


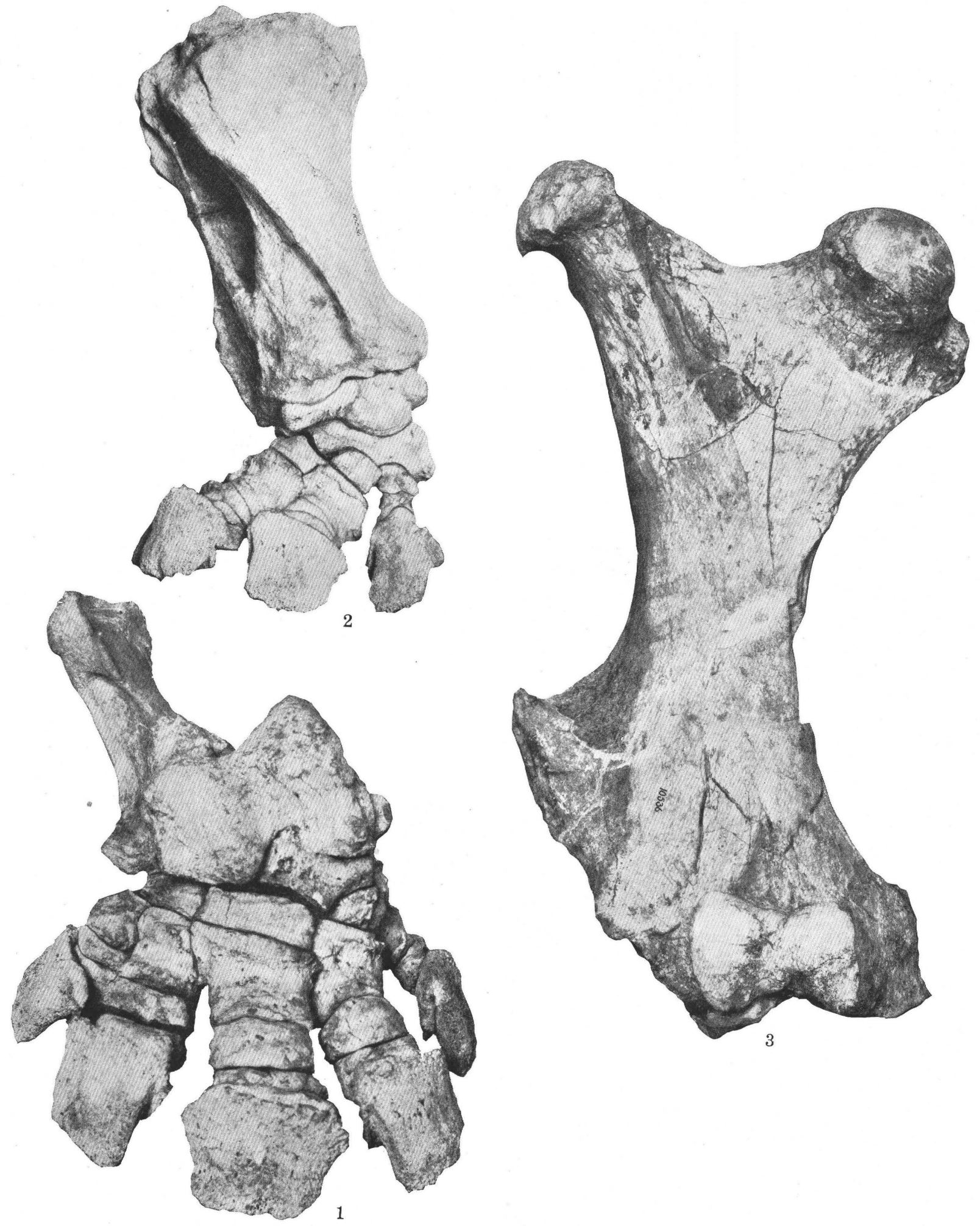

FOSSIL MAMMALS FROM SAN PEDRO VALLEY, ARIZ.

Bones of Glyptotherium arizonae Gidley, n. sp., type (No. 10536, U. S. Nat. Mus.). 1, Right hind foot, plantar view, a little less than one- half natural size; 2, right tibia, fibula, and hind foot, inner side view, a little less than one-third natural size; 3, right femur, anterior view, a little less than one-third natural size 
U. S. GEOLOGICAL SURVEY

PROFESSIONAL PAPER 140 PLATE XLIV
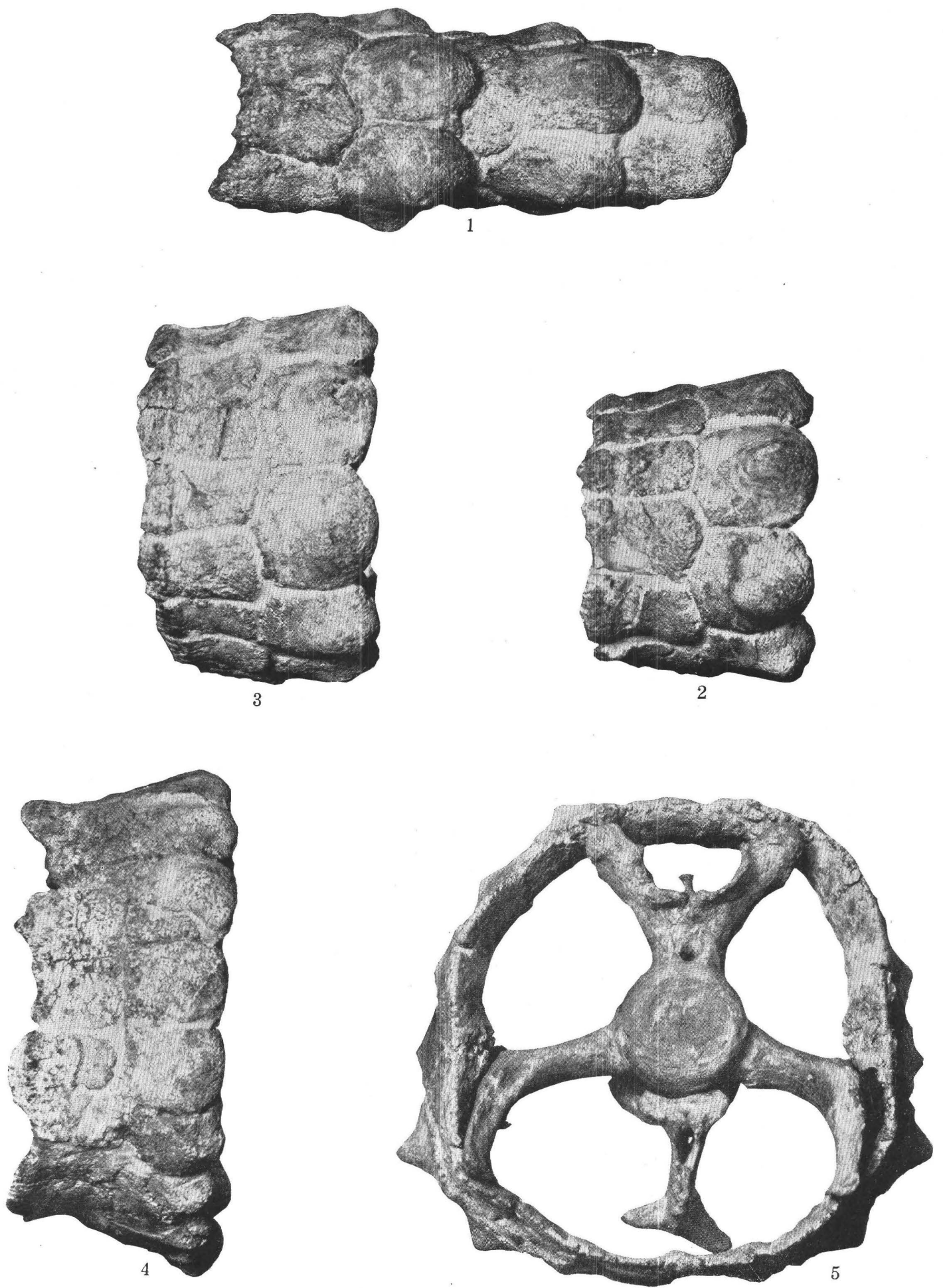

FOSSIL MAMMAIS FROM SAN PEDRO VALLEY, ARIZ.

Elements of tail sheath of Glyptotherium arizonae Gidley, n. sp., paratype (No, 10537, U. S. Nat. Mus.). All about one-third natural size. 1, Terminal tube of tail sheath, dorsal view; 2, seventh ring of tail sheath, dorsal view; 3 , sixth ring of tail sheath, dorsal view; 4 , fourth ring of tail sheath, dorsal view; 5 , anterior view of fourth ring of tail sheath with its corresponding vertebra and chevron in place 